\title{
Seasonal variability of submarine melt rate and circulation in an East Greenland fjord
}

\author{
R. Sciascia, ${ }^{1,2,3}$ F. Straneo, ${ }^{4}$ C. Cenedese,${ }^{4}$ and P. Heimbach ${ }^{3}$ \\ Received 13 September 2012; revised 14 February 2013; accepted 22 February 2013; published 17 May 2013.
}

[1] The circulation in a glacial fjord driven by a large tidewater glacier is investigated using a nonhydrostatic ocean general circulation model with a melt rate parameterization at the vertical glacier front. The model configuration and water properties are based on data collected in Sermilik Fjord near Helheim Glacier, a major Greenland outlet glacier. The approximately two-layer stratification of the fjord's ambient waters causes the meltwater plume at the glacier front to drive a "double cell" circulation with two distinct outflows, one at the free surface and one at the layers' interface. In summer, the discharge of surface runoff at the base of the glacier (subglacial discharge) causes the circulation to be much more vigorous and associated with a larger melt rate than in winter. The simulated "double cell" circulation is consistent, in both seasons, with observations from Sermilik Fjord. Seasonal differences are also present in the vertical structure of the melt rate, which is maximum at the base of the glacier in summer and at the layers' interface in winter. Simulated submarine melt rates are strongly sensitive to the amount of subglacial discharge, to changes in water temperature, and to the height of the layers. They are also consistent with those inferred from simplified one-dimensional models based on the theory of buoyant plumes. Our results also indicate that to correctly represent the dynamics of the meltwater plume, care must be taken in the choice of viscosity and diffusivity values in the model.

Citation: Sciascia, R., F. Straneo, C. Cenedese, and P. Heimbach (2013), Seasonal variability of submarine melt rate and circulation in an East Greenland fjord, J. Geophys. Res. Oceans, 118, 2492-2506, doi:10.1002/jgrc.20142.

\section{Introduction}

[2] Net mass loss from the Greenland Ice Sheet more than doubled over the last decade [Rignot and Kanagaratnam, 2006] and, at present, accounts for one quarter of global sea level rise [Cazenave and Llovel, 2009; Milne et al., 2009; Bamber et al., 2012]. About half of the mass loss is attributed to an increased ice discharge from the acceleration of outlet glaciers in west and southeast Greenland [van den Broeke et al., 2009] which started in the mid1990s [Joughin et al., 2004; Stearns and Hamilton, 2007; Howat et al., 2007, 2008]. The acceleration began at the tidewater termini of outlet glaciers where ice-ocean interface processes play a crucial role [Thomas, 2004; Vieli and Nick, 2011]. An increasing number of studies suggest that it was triggered by the warming of waters around Greenland

\footnotetext{
${ }^{1}$ Doctorate program in Fluid Dynamics, Politecnico di Torino, Italy.

${ }^{2}$ Institute of Atmospheric Sciences and Climate, CNR, Torino, Italy.

${ }^{3}$ Massachusetts Institute of Technology, Department of Earth, Atmospheric and Planetary Sciences, Cambridge, Massachusetts, USA.

${ }^{4}$ Department of Physical Oceanography, Woods Hole Oceanographic Institution, Woods Hole, Massachusetts, USA.
}

Corresponding author: R. Sciascia, Massachusetts Institute of Technology, Department of Earth, Atmospheric and Planetary Sciences, Cambridge MA, USA. (sciascia@mit.edu)

(C)2013. American Geophysical Union. All Rights Reserved. 2169-9275/13/10.1002/jgrc.20142
[Holland et al., 2008; Murray et al., 2010; Motyka et al., 2011; Christoffersen et al., 2011]. The exact chain of events is still unclear, but it has been proposed that warming of ocean waters coming in contact with Greenland's glaciers may have resulted in increased submarine melting at their marine termini and have impacted glacier stability by thinning and ungrounding the termini and/or affecting calving (see review by Vieli and Nick [2011]). Therefore, submarine melting, and the processes and parameters controlling its magnitude and variability, need to be understood if we are to improve our understanding of past glacier variability in Greenland and its future evolution. This is a challenging problem given the difficulties of observing the ice-ocean interface and modeling the wide range of space and time scales involved. Furthermore, from a modeling perspective, the parameterization of the ice-ocean boundary layer derived from laboratory experiments of heat and mass exchange across a hydraulic rough surface [Yaglom and Kader, 1974] was applied mostly to Antarctica's floating ice shelves. Given the different properties of Antarctic ice stream/shelf systems and Greenland outlet glaciers (e.g. quasi-horizontal versus quasi-vertical geometry, see, e.g., Truffer and Echelmeyer [2003]), the different water mass properties with which they are in contact, and the limited number of studies on Greenland's glaciers, it is unclear whether these parameterizations can be readily applied to Greenland's outlet glaciers. Recent studies suggest that large 
uncertainties regarding simulated melt rates remain even for Antarctic ice shelves [Mueller et al., 2012].

[3] In Greenland, tidewater glaciers terminate in long, narrow, deep fjords which connect the glaciers to the surrounding continental shelf waters [Straneo et al., 2012]. Submarine melting at the glacier termini results from a net transport of oceanic heat to the glacier and depends on a range of oceanic and glaciological processes. In the immediate vicinity of the glacier, the circulation is thought to be dominated by the buoyancy-driven circulation generated by the glacier itself through the discharge of fresh, buoyant water both at the surface and at depth [Chu et al., 2009; Das et al., 2008]. In the simplest scenario in which the glacier (buoyancy)-driven circulation is the only relevant circulation, the leading paradigm is that the transport of heat to the glacier is governed by a steady estuarine-like circulation [Hanna et al., 2009; Rignot et al., 2010; Motyka et al., 2011] as observed for tidewater glaciers in Alaska [Motyka et al., 2003]. In this case, a buoyant plume develops and is composed of glacially modified and entrained ambient waters. The plume rises vertically near the ice-ocean interface, producing a buoyant current of relatively fresh water moving away from the glacier near the ocean's free surface. In order to conserve volume, and because of entrainment, an inflow of ambient waters is generated at depth to balance the net surface outflow. In this case, the net heat transport to the glacier (and consequently, the submarine melt rate) is due to the difference between the heat transported by warm deep waters flowing towards the glacier and that by cold surface waters flowing away from the glacier. Typically, this circulation is thought of as a fast, thin surface outflow and a slow, thick, deep inflow such that the net top-to-bottom volume transport remains balanced.

[4] The direct applicability of this paradigm to Greenland's fjords, however, is complicated by several factors, amongst which are fjord stratification, seasonal variability of subglacial discharge, as well as forcings external to the fjord/glacier system (e.g., continental shelf variability at the mouth of the fjord or local winds). The estuarine paradigm assumes that the fjord waters are mostly unstratified, except for the density contrast between the freshwater discharged by the glacier and the ambient water having a single density. Instead, multiple surveys of Greenland's major fjords have shown that these are typically filled with at least two distinct water masses: a relatively warm, salty water of Atlantic origin at depth (AW) and relatively cold, freshwater of Polar origin in the upper layer (PW) [Azetsu-Scott and Tan, 1997; Holland et al., 2008; Straneo et al., 2010, 2012]. Thus, the buoyant plume near the ice-front rises vertically within a water column whose properties (including density) vary with depth. As suggested both by theoretical and laboratory studies [Huppert and Josberger, 1980; Huppert and Turner, 1980] and by recent observations [Straneo et al., 2011], this may result in a more complex circulation (and hence, a more complex pattern of heat transport to the glacier) since the rising buoyant plume may reach its neutral density level before it reaches the free surface.

[5] The presence of different freshwater masses inside the fjord introduces additional elements of complexity in the estimate of submarine melting. The buoyant plume is forced by two distinct glacial waters sources: one due to subglacial discharge, and one due to submarine melting. Herein, by subglacial discharge, we indicate the portion of surface melting occurring on the glacier surface, in contact with air, that is discharged at the glacier base, and by submarine melting, the melting of the glacier front immersed in water. As argued in recent studies, the subglacial discharge that enters the fjord at depth is likely to be a major contributor to the dynamics (e.g., Motyka et al. [2003]) by forcing the buoyant plume at the glacier front and, as such, to be a primary control on the submarine melt rate [Jenkins, 2011; $X u$ et al., 2012]. Yet how the submarine melt rate depends on the magnitude and seasonal variability of subglacial discharge remains largely unknown.

[6] Some progress on the dynamics near the ice-ocean interface has been made using simplified one-dimensional models based on the theory of buoyant plumes [Hellmer and Olbers, 1989; Jenkins, 1991, 2011]. MacAyeal and Jacobs [1985] applied a plume model to the overturning circulation beneath ice shelves where the submarine melting generated by ice-ocean interaction is a distributed source of buoyancy. Without an initial localized buoyancy source (i.e., subglacial discharge), the development of a turbulent plume can be treated in analogy with the theory of convection against a heated plate [Wells and Worster, 2008]. More recently, Jenkins [2011] developed a simplified model, analogous to MacAyeal and Jacobs [1985], for the dynamics at the grounding line of ice shelves and tidewater glaciers where the main forcing is assumed to be the buoyancy flux generated by the subglacial discharge. In the case of Greenland's tidewater glaciers, this assumption is likely valid for the summer but not necessarily for winter, when the shutdown of surface runoff strongly reduces the buoyancy source at the base of the glacier terminus. Given the inherent simplicity of these models, their ability to capture the complexity of the dynamics may be limited, and the effects of the dynamics neglected in these models needs to be addressed. Many of the relevant oceanic processes such as the circulation generated by the glacier subglacial discharge, the fjord's circulation itself, and the effect of viscosity and diffusivity on the circulation are not captured by these one-dimensional plume models. These effects can be included by using more complex models such as general circulation models (GCM). Recently, Xu et al. [2012] have shown that high-resolution ocean models can be useful tools to investigate the complex ocean dynamics near the ice-ocean interface. Although turbulence, boundary layer dynamics, and entrainment are still parameterized at the resolution used both in $X u$ et al. [2012] and in the present study, the use of high-resolution ocean models can highlight the limitation and strength of simplified one-dimensional plume models.

[7] Here we investigate the ice-ocean boundary layer dynamics and the fjord circulation forced by glacial boundary conditions (subglacial discharge and submarine melting) using a high-resolution, nonhydrostatic ocean general circulation model (GCM) with a thermodynamical melt rate parameterization of a vertical glacier terminus. The configuration is an idealized version of a major glacier/fjord system, Helheim Glacier and Sermilik Fjord in southeast Greenland. Field data collected both in summer and winter provide the initial and boundary conditions for this problem and are used for comparison. Specifically, we investigate differences between summer and winter conditions due to changes in 
subglacial discharge as well as water properties. The goal of this study is to obtain estimates of submarine melting for Helheim Glacier and its dependency on subglacial discharge, temperature, and stratification of ambient waters. The novelty of this study compared to previous studies using one-dimensional plume models (e.g., Jenkins [2011]) is in the use of a GCM which includes more dynamical effects, in particular the circulation generated by glacial forcing and the effect of viscosity and diffusivity on the circulation. Compared with previous studies using a GCM $[X u$ et al., 2012], this study differs in terms of regime investigated. We focus mainly on the regime in which the meltwater plume generates a "double cell" circulation with two distinct outflows, one at the free surface and one at the layers' interface, similar to that inferred from observations in Sermilik Fjord [Straneo et al., 2011]. In particular, we propose a scaling argument to characterize the dynamical regime of the circulation generated by the glacier. Our results suggest that velocity-dependent turbulent transfer coefficients substantially modify not only the magnitude of the submarine melting but also its vertical distribution. Hence, our study provides new insight into the dynamics regulating the submarine melting and points to possible fundamental dynamics still missing in the formulation of the problem.

[8] The model and its setup are described in section 2 . These are followed by a review of the theory of buoyant line plumes, section 3 . The main findings are presented in sections 4 to 8 followed by a summary and conclusions in the final section.

\section{Model Setup}

[9] To investigate the circulation and melting at the terminus of a Greenland tidewater glacier, we consider a vertical glacier front at the head of a rectangular fjord and assume that it is grounded at the bottom of the fjord (Figure 1). The configuration is chosen to broadly match the features of Helheim Glacier, a large tidewater glacier in southeast Greenland, which discharges into Sermilik Fjord $\left(66^{\circ} \mathrm{N}, 38^{\circ} \mathrm{W}\right)$ [Straneo et al., 2010]. The real fjord's width varies from 4 to $10 \mathrm{~km}$ and is about $100 \mathrm{~km}$ long, with depths varying from $900 \mathrm{~m}$ at the mouth to around $600 \mathrm{~m}$ at the head [Schjøth et al., 2012]. Hydrographic surveys [Straneo et al., 2010] have shown that property changes occur primarily in the along-fjord direction and that acrossfjord gradients are small. This is consistent with the fact that the Rossby radius of deformation and fjord width are roughly equal and, therefore, that rotation has a secondary effect on the fjord dynamics. Hence, we simplify the problem to a two-dimensional one, assuming no variations in the across-fjord direction. As a result of this simplification, this setup is ill-suited to study across-fjord variations induced, for example, by a localized (in the horizontal) subglacial discharge channel. Yet overall, it is an important first step to understand the leading dynamics of the problem.

[10] Helheim Glacier terminus is represented as an $H_{T}=$ $600 \mathrm{~m}$ deep wall with a vertical front (i.e., no floating ice tongue) typical of the present state of Greenland's outlet glaciers [Joughin et al., 2004]. Subglacial discharge is confined near the bottom of the glacier where the input of freshwater is likely to have the largest impact on the fjord dynamics. It is also consistent with the notion that the bulk

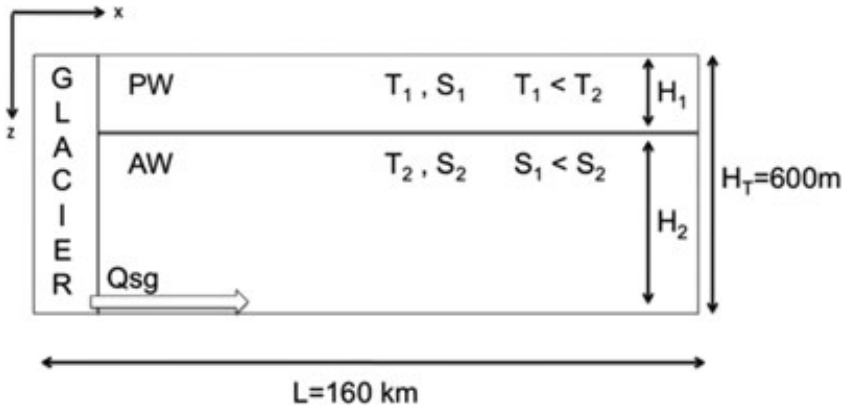

Figure 1. Model geometry with the glacier front on the left side and the mouth of the fjord on the right side of the domain. PW (Polar waters) layer with temperature $T_{1}$ and salinity $S_{1}$. AW (Atlantic waters) layer with temperature $T_{2}$ and salinity $S_{2}$. Subglacial discharge (Qsg) is confined to the lowest two cells near the bottom. Horizontal and vertical resolution at the glacier front are $10 \mathrm{~m}$.

of the seasonal surface runoff is discharged at the base of the glacier through a series of drainage channels [Andreasen, 1985; Zwally et al., 2002; Das et al., 2008; Catania et al., 2008].

\subsection{The Model}

[11] The MITgcm (http://mitgcm.org) is a substantially evolved version of Marshall et al. [1997a, 1997b] and Adcroft et al. [2004]. It solves the Boussinesq form of the Navier-Stokes equations on a generalized curvilinear grid. The finite-volume discretization is rendered on a horizontal Arakawa $\mathrm{C}$-grid, and with vertical $z$-levels. The model has been used to simulate a wide range of geophysical phenomena, from large-scale ocean circulation to smallscale processes, both in realistic [Magaldi et al., 2011] and idealized [Spall, 2011] setups.

[12] In our study, we consider a high-resolution, nonhydrostatic setup [Marshall et al., 1998] with a modified version of the United Nations Educational, Scientific and Cultural Organization (UNESCO) equation of state by Jackett and McDougall [1995]. In this configuration, mixing processes are permitted up to the grid scale of the model. Previous studies have applied similar high-resolution formulations to problems such as internal waves, overflows, and convection [Visbeck et al., 1996; Legg and Adcroft, 2003; Legg et al., 2006]. We perform two-dimensional idealized experiments (Figure 1) with $10 \mathrm{~m}$ uniform vertical resolution and a telescopic horizontal resolution ranging from $10 \mathrm{~m}$ at the glacier front to $500 \mathrm{~m}$ at the mouth of the fjord. The model width in the $y$-direction is one grid cell of size $L=10 \mathrm{~m}$. Three-dimensional (3-D) simulations with a $6 \mathrm{~km}$ wide fjord (not shown) reveal that the across fjord variability and the differences between the 3-D and 2D simulations are small provided that the forcing applied (e.g., subglacial discharge) is 2-D. The advantage of using a 2-D setup is that the reduced computational cost allows us to perform a large number of simulations.

[13] Subgrid scale processes are parameterized using a Laplacian eddy diffusion of temperature, salinity, and momentum with grid size-rescaled constant coefficients. At the scales adopted $(10 \mathrm{~m} \times 10 \mathrm{~m})$, diffusive $(\kappa)$ and viscous $(v)$ processes are dominated by turbulence and consequently 
Table 1. Dimensional Parameters and Variables $\left(T_{b}, S_{b}, q\right)$ Used in the Simulations

\begin{tabular}{lccc}
\hline Symbol & Description & Value & Unit \\
\hline$\rho$ & Density of water & 1030 & $\mathrm{~kg} \mathrm{~m}^{-3}$ \\
$c_{p}$ & Specific heat capacity & 3974 & $\mathrm{Jkg}^{-1} \mathrm{~K}^{-1}$ \\
$C_{d}^{1 / 2} \Gamma_{T}$ & Thermal Stanton number & $1.1 \cdot 10^{-3}$ & \\
$C_{d}^{1 / 2} \Gamma_{S}$ & Diffusion Stanton number & $3.1 \cdot 10^{-5}$ & \\
$L_{i}$ & Latent heat of fusion of ice & 334000 & $\mathrm{~J} \mathrm{~kg}^{-1}$ \\
$\rho_{i}$ & Density of ice & 916 & $\mathrm{~kg} \mathrm{~m}^{-3}$ \\
$c_{p, i}$ & Heat capacity of ice & 3974 & $\mathrm{Jkg}^{-1} \mathrm{~K}^{-1}$ \\
$k$ & Heat diffusivity & $1.54 \cdot 10^{-6}$ & $\mathrm{~m}^{2} \mathrm{~s}^{-1}$ \\
$\lambda_{1}$ & Liquidus slope & -0.0573 & ${ }^{\circ} \mathrm{C}$ \\
$\lambda_{2}$ & Liquidus intercept & 0.0832 & ${ }^{\circ} \mathrm{C}$ \\
$\lambda_{3}$ & Liquidus slope & $-7.53 \cdot 10^{-8}$ & ${ }^{\circ} \mathrm{CPa}^{-1}$ \\
$T_{w}$ & Water temperature & see Table 2 & ${ }^{\circ} \mathrm{C}$ \\
$T_{i}$ & Ice temperature & -10 & ${ }^{\circ} \mathrm{C}$ \\
$S_{w}$ & Water salinity & see Table 2 & $\mathrm{psu}^{-1}$ \\
$v_{H}$ & Horizontal viscosity & $2.5 \cdot 10^{-1}$ & $\mathrm{~m}^{2} \mathrm{~s}^{-1}$ \\
$v_{V}$ & Vertical viscosity & $10^{-3}$ & $\mathrm{~m}^{2} \mathrm{~s}^{-1}$ \\
$\kappa_{H}$ & Horizontal diffusion & $2.5 \cdot 10^{-1}$ & $\mathrm{~m}^{2} \mathrm{~s}^{-1}$ \\
$\kappa_{V}$ & Vertical diffusion & $2 \cdot 10^{-5}$ & $\mathrm{~m}^{2} \mathrm{~s}^{-1}$ \\
$T_{b}$ & Boundary temperature & & ${ }^{\circ} \mathrm{C}$ \\
$S_{b}$ & Boundary salinity & & $\mathrm{psu}^{-1}$ \\
$q$ & Melt rate of ice & & $\mathrm{kg} \mathrm{m}^{-2} \mathrm{~s}^{-1}$ \\
\hline
\end{tabular}

are of the same order of magnitude. Hence, the choice of dimensional parameters (Table 1) is such that the horizontal Prandtl number $P r$ is equal to one and the properties vary without discontinuities at the grid scale of the model. Depending on the characteristics of the simulations, the model is integrated with a time step ranging from 1 to $20 \mathrm{~s}$ (Table 2).

[14] The boundary conditions of the model are free surface at the top, rigid boundaries with no-slip boundary conditions at the bottom and left side (i.e., glacier front), and open boundary on the right side (i.e., fjord's mouth) with a sponge layer restoring temperature and salinity profiles to those prescribed as initial conditions. The domain is sufficiently long $(160 \mathrm{~km})$ for the simulations to reach a steady state before the open boundary conditions influence the circulation at the glacier front. In section 5.1, we describe a series of sensitivity experiments supporting our assumption that the leading order dynamics in the fjord do not depend on the exact choice of parameters such as horizontal resolution, $\nu$, or $\kappa$.

\subsection{Melt Rate Parameterization}

[15] The thermodynamical melt rate parameterization of the ice-ocean boundary (equations (1)-(3)) is based on the Hellmer and Olbers [1989] and Holland and Jenkins [1999] three equations model

$$
\begin{gathered}
T_{b}=\lambda_{1} S_{b}+\lambda_{2}+\lambda_{3} P_{b}, \\
c_{p} \rho_{i} \gamma_{T}\left(T_{w}-T_{b}\right)=-L_{i} q-\rho_{i} c_{p, i} k\left(T_{i}-T_{b}\right), \\
\rho_{i} \gamma_{S}\left(S_{w}-S_{b}\right)=-S_{b} q .
\end{gathered}
$$

Equation (1) is the linear equation for the freezing temperature of seawater, where $T_{b}, P_{b}$, and $S_{b}$ are the temperature, pressure, and salinity at the ice-ocean boundary, respectively, and $\lambda_{1-3}$ are constants. Together with the conservation of heat, equation (2), and salinity, equation (3), these equations describe the thermodynamical equilibrium at the ice-ocean interface. $T_{w}$ and $S_{w}$ are the seawater temperature and salinity, $T_{i}$ is the ice temperature, $\gamma_{T, S}$ are the turbulent transfer coefficients for temperature and salinity, and the other parameters in equations (1)-(3) are defined in Table 1. This parameterization has been used, in the context of the MITgcm, to model sub-ice-shelf melting around Antarctica [Losch, 2008; Heimbach and Losch, 2012; Schodlok et al., 2012] and submarine melt rates of a Greenland tidewater glacier [Xu et al., 2012]. An additional, step not described in any of these studies, but correctly implemented in the MITgcm, is the treatment of an advection term in the boundary conditions (lateral for a vertical ice front) for the tracer tendency equations, following Jenkins et al. [2001].

[16] While most of the terms in the thermodynamical parameterization of the ice-boundary (equations (1)-(3)) are physical constants that can be easily measured, the same cannot be said for the turbulent transfer coefficients $\gamma_{T, S}$ which represent a parameterization of the effects of turbulence in the ice-ocean boundary layer. Earlier parameterizations of the turbulent transfer coefficients by Hellmer and Olbers [1989] adopted constant values for $\gamma_{T, S}$.

\begin{tabular}{|c|c|c|c|c|c|c|c|c|c|c|c|}
\hline & $Q s g\left[\mathrm{~m}^{3} \mathrm{~s}^{-1}\right]$ & $\Delta x[\mathrm{~m}]$ & $\Delta y[\mathrm{~m}]$ & $\Delta t[\mathrm{~s}]$ & $\gamma_{T, S}$ & $H_{2}[\mathrm{~m}]$ & $T_{1}\left[{ }^{\circ} \mathrm{C}\right]$ & $T_{2}\left[{ }^{\circ} \mathrm{C}\right]$ & $S_{1}[\mathrm{psu}]$ & $S_{2}[\mathrm{psu}]$ & $\overline{s m r}\left[\mathrm{myr}^{-1}\right]$ \\
\hline WIN & 0 & 10 & 10 & 10 & Variable & 450 & -1.5 & 4 & 32.9 & 34.6 & 70 \\
\hline SUM & 4.3 & 10 & 10 & 5 & Variable & 450 & -1.5 & 4 & 32.9 & 34.6 & 738 \\
\hline WIN50 & 0 & 50 & 10 & 20 & Variable & 450 & -1.5 & 4 & 32.9 & 34.6 & 34 \\
\hline WIN20 & 0 & 20 & 10 & 10 & Variable & 450 & -1.5 & 4 & 32.9 & 34.6 & 42 \\
\hline WIN5 & 0 & 5 & 10 & 1 & Variable & 450 & -1.5 & 4 & 32.9 & 34.6 & 57 \\
\hline $\mathrm{WIN} \gamma$ & 0 & 10 & 10 & 10 & Constant & 450 & -1.5 & 4 & 32.9 & 34.6 & 59 \\
\hline SUMs & 4.3 & 10 & 10 & 5 & Variable & 450 & 0.5 & 3 & 32.5 & 34.5 & 551 \\
\hline SUMd & $0.29-8.7$ & 10 & 10 & 5 & Variable & 450 & -1.5 & 4 & 32.9 & 34.6 & $73-1111$ \\
\hline TEMP & 0 & 10 & 10 & 10 & Variable & 450 & -1.5 & $0-8$ & 32.9 & 34.6 & $0.7-172$ \\
\hline TEMPs & 4.3 & 10 & 10 & 10 & Variable & 450 & -1.5 & $0-8$ & 32.9 & 34.6 & $170-1104$ \\
\hline INTER & 0 & 10 & 10 & 10 & Variable & $50-550$ & -1.5 & 4 & 32.9 & 34.6 & $0.4-104$ \\
\hline INTERs & 4.3 & 10 & 10 & 10 & Variable & $50-550$ & -1.5 & 4 & 32.9 & 34.6 & $225-677$ \\
\hline SALT & 0 & 10 & 10 & 10 & Variable & 450 & -1.5 & 4 & 32.9 & $34-35$ & $69-66$ \\
\hline SALTs & 4.3 & 10 & 10 & 10 & Variable & 450 & -1.5 & 4 & 32.9 & $34-35$ & $776-686$ \\
\hline
\end{tabular}
Holland and Jenkins [1999] and more recently Jenkins et al.

Table 2. Value of Dimensional Parameters Used in Each Simulation (Section 2.5 for Details) 
[2010] showed that a parameterization with a functional dependence on water velocities produces a better agreement with submarine melt rate measurements. Hence, in our formulation we use a parameterization that includes a functional dependence on the water velocity. Explicitly, the transfer coefficients $\gamma_{T, S}$ are defined as

$$
\gamma_{T, S}=C_{d}^{1 / 2} \Gamma_{T, S} U_{b}
$$

where $U_{b}=\sqrt{u_{b}^{2}+w_{b}^{2}}$ is the magnitude of the velocity at the ice-ocean boundary. $C_{d}^{1 / 2} \Gamma_{T, S}$ are the thermal and diffusive Stanton numbers [Steele et al., 1989], and their values are those used by [Jenkins et al., 2010; Jenkins, 2011]. Parameter values and variables used in the equations are given in Table 1.

[17] The turbulent transfer coefficients are related to the far field current away from the ice-ocean boundary layer [Jenkins et al., 2010] but, at present, it is unclear what this velocity actually is. For quasi-horizontal ice shelves, like those present in Antarctica, the relevant velocities are the horizontal ones parallel to the ice shelf. In the case of significant tidal flows, such as under Ross ice shelf, these velocities are assumed to be dominated by the magnitude of the tidal flows [Jenkins et al., 2010]. In the case of a vertical glacier front, the relevant velocity is likely that of the buoyant plume with additional potential contributions from tidal flows, internal fjord modes, and externally driven flows [Jenkins et al., 2010; Jenkins, 2011]. If we consider the glacier-driven circulation alone, plume theory suggests that at the ice-ocean boundary, the vertical velocity is much larger than the horizontal velocity induced by entrainment. Hence, at the vertical glacier front, the velocity dependence of the turbulent transfer coefficients is likely determined mainly by the vertical velocity of the buoyant plume.

\subsection{Boundary Conditions - Subglacial Discharge}

[18] As we show below, among the parameters and forcing explored here, the largest seasonal control on the fjord's circulation and the submarine melt rate is the subglacial discharge. In summer, large amounts of surface runoff are thought to find their way to the bed of Greenland's glacier and discharge freshwater at depth [Das et al., 2008]. Evidence for these fresh intrusions in summer and their absence in winter in Sermilik Fjord is discussed in Straneo et al. [2011]. To investigate this seasonal variability, we consider two distinct seasonal regimes: a winter regime with no subglacial discharge, and a summer regime with subglacial discharge. Geothermal and frictional melting at the base of the glacier are much smaller than submarine melting and subglacial discharge [Mernild et al., 2010]. Thus, we assume that the melting generated by these two processes can be neglected in both seasons. To quantify a plausible range for the summer subglacial discharge in our simulations, we proceed as follows. Andersen et al. [2010] estimate a summer surface runoff of $Q_{\mathrm{TOT}} \sim 174 \mathrm{~m}^{3} \mathrm{~s}^{-1}$ entering the fjord from Helheim Glacier catchment basin through an unknown number of drainage channels of unknown dimensions. Since our simulations are limited to a $10 \mathrm{~m}$ wide vertical slice of the fjord and glacier, we need to rescale discharge rates accordingly. To do so, we consider two scenarios that may provide plausible lower and upper limits for the subglacial discharge forcing to be used in our simulations. For the lower bound, we consider the case in which the total subglacial discharge is uniformly distributed along the entire base of Helheim Glacier. Assuming that Helheim Glacier is $6 \mathrm{~km}$ wide, this amounts to a discharge flux of $0.029 \mathrm{~m}^{2} \mathrm{~s}^{-1}$ per unit width. Since our 2-D slice is $10 \mathrm{~m}$ wide (i.e., it has the width of a grid cell), the uniformly distributed flux that provides the lower limit for our simulations amounts to a rescaled subglacial discharge $Q s g=0.29 \mathrm{~m}^{3} \mathrm{~s}^{-1}$. For the upper limit, we assume that Helheim's entire rescaled subglacial discharge occurs through a single opening that is $200 \mathrm{~m}$ wide. Since our 2-D slice is $10 \mathrm{~m}$ wide, this upper limit amounts to $Q s g=8.7 \mathrm{~m}^{3} \mathrm{~s}^{-1}$ (in the following, Qsg refers to rescaled discharge rates in the way just described). In examining the impact of subglacial discharge on the dynamics at the ice front, we perform a series of experiments with discharge values ranging between these two extremes: the "distributed" scenario and the "single" channel scenario. It is important to stress that the problem addressed here is two-dimensional in nature and that we are not investigating the 3-D dynamics associated with the discharge by a localized channel but rather the 2-D dynamics associated with the flux expected from a channel.

[19] We impose a subglacial discharge with zero salinity, at the freezing temperature for the given depth, and with an initial horizontal velocity computed from the total discharge $u_{Q} s g=Q s g / A$, where $A$ is the area of the model cells where the subglacial discharge is applied $(20 \mathrm{~m}$ high and $10 \mathrm{~m}$ wide). Some plume models [Mugford and Dowdeswell, 2011] derive the initial subglacial discharge velocity from the Manning equation for open channel flows [Chow, 1959] which gives rise to larger initial velocities. We also performed experiments using these larger velocities but found negligible impact on our results. We conclude that the dynamics is more sensitive to the subglacial discharge magnitude than to the prescribed initial velocity. The subglacial discharge is treated as a "virtual mass flux" in the sense of Huang [1993], i.e., instead of adding a real freshwater flux to the continuity equation, corresponding source terms are added to the tracer and momentum conservation equations. This choice is volume-conserving and allows us to minimize the number of parameters necessary to define the problem by imposing open boundary conditions only on temperature and salinity fields. Nevertheless, an advective flux through a nonmaterial surface implied by the melting is taken into account, following Jenkins et al. [2001].

\subsection{Initial Conditions}

[20] Sermilik Fjord is filled with two main water masses [Straneo et al., 2010]: a cold and fresh layer of polar waters (PW) overlying warm, salty Atlantic waters (AW) (Figure 1). The winter profiles (Figure 2a) clearly show a two-layer stratification of temperature and salinity, and hence density. In summer (Figure 2b), the stratification is more complex, reflecting the presence of large volumes of glacially modified waters in the upper 100-200 $\mathrm{m}$ [Straneo et al., 2011]. The winter runs were initialized with a twolayer stratification in which the temperature and salinity in each layer are equal to the layer average observed during a winter survey of Sermilik Fjord (Table 2). In summer, magnitude and spatial distributions of temperature and salinity 

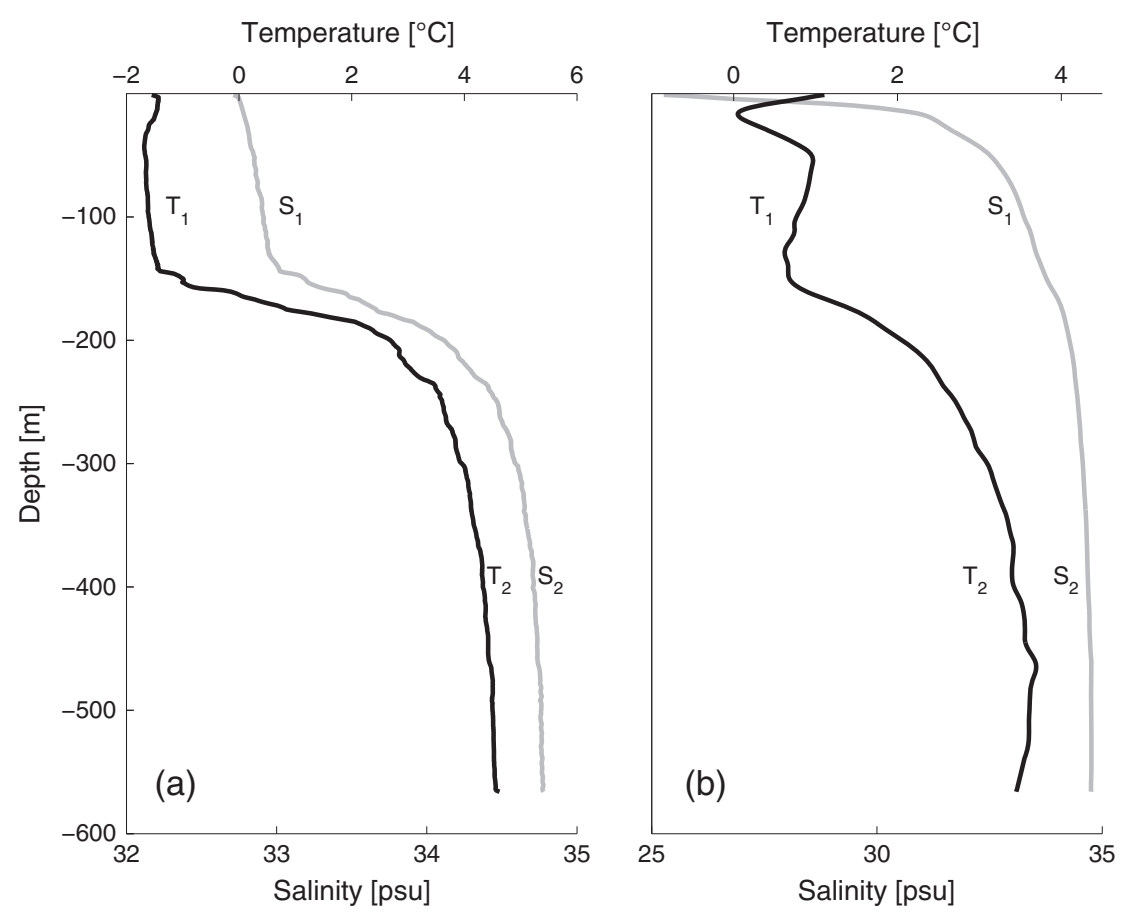

Figure 2. Sermilik Fjord temperature and salinity vertical profiles at mid-fjord. Measurements were taken in (a) winter 2010 and (b) summer 2009 [Straneo et al., 2011].

differ from winter conditions (Figure 2b). For simplicity, and to reduce the number of variables changed simultaneously, we initialize the model with the same idealized two-layer stratification. In summer, we consider two different scenarios: one in which the temperature and salinity are identical to the winter runs (SUM, Table 2), and one in which the temperature and salinity are those observed in summer (SUMs, Table 2 and Figure 2b). The same water temperature and salinity profiles used for the initial conditions in the fjord are used as relaxation profiles at the open boundary. The interface between the two water masses is set to a depth of $150 \mathrm{~m}$ with the exception of the runs described in section 6 (INTER, INTERs Table 2). The flow is assumed to be initially at rest, and analysis is carried out after a spin-up period of 8 days.

\subsection{Model Experiments}

[21] We conduct a series of experiments aimed at investigating the dynamics of the glacier-driven circulation in both winter and summer conditions, and its sensitivity to model parameters. In particular, we focus on the submarine melt rate's dependence on the subglacial discharge rate and the fjord's bottom layer temperature, salinity, and thickness. The experiments are briefly described below and listed in Table 2.

[22] Control Experiment - WIN. As a baseline, we perform a control experiment with winter water properties (Figure 2a) and without subglacial discharge.

[23] Summer Experiment - SUM. We explore the effect of summer subglacial discharge on fjord dynamics through a simulation with the same water properties as for the WIN experiment, but with a steady subglacial discharge equal to $Q s g=4.3 \mathrm{~m}^{3} \mathrm{~s}^{-1}$ equivalent to a total discharge fluxed through a $400 \mathrm{~m}$ wide opening.

[24] Summer Experiment - SUMs. Same as the SUM simulation except for initial water properties chosen to be those observed during the summer survey (Figure 2b). The idealized two-layer stratification is maintained.

[25] Sensitivity to Subglacial Discharge - SUMd. Subglacial discharge rate is highly variable during summer. In this set of experiments, we explore the influence of the subglacial discharge rate on submarine melting and fjord circulation by varying the subglacial discharge within the range $Q s g=0.29-8.7 \mathrm{~m}^{3} \mathrm{~s}^{-1}$. For each experiment, we consider a steady subglacial discharge.

[26] Sensitivity to Grid Resolution - WIN5, WIN20, WIN50. With this set of experiments, we explore the sensitivity of submarine melt rate to numerical horizontal resolution ( $5 \mathrm{~m}, 20 \mathrm{~m}$, and $50 \mathrm{~m}$, respectively).

[27] Sensitivity to Velocity - WIN $\gamma$. In all previous experiments, the turbulent transfer coefficients (equation (4)) are functions of the velocity $U_{b}$ at the iceocean interface. Here we consider how the results differ if $U_{b}$ is assumed to be constant. All other parameters are identical to the WIN run.

[28] Sensitivity to AW Temperature - TEMP and TEMPS. In these experiments, we vary the temperature of the AW layer from $0^{\circ} \mathrm{C}$ to $8^{\circ} \mathrm{C}$ with $1^{\circ} \mathrm{C}$ increments, both in the WIN (TEMP) and SUM (TEMPs) setup.

[29] Sensitivity to AW Thickness - INTER and INTERs. In these experiments, we vary the AW thickness, $\mathrm{H}_{2}$, from $50 \mathrm{~m}$ to $550 \mathrm{~m}$ with $50 \mathrm{~m}$ increments, both in the WIN (INTER) and SUM (INTERs) setup. 
[30] Sensitivity to AW Salinity - SALT and SALTS. In these experiments, we vary the AW salinity, $S_{2}$, from $34 \mathrm{psu}$ to 35 psu with 0.25 psu increments, both in the WIN (SALT) and SUM (SALTs) setup.

[31] We compare simulations not only in terms of water properties and velocity but also in terms of submarine melt rate at a given depth, $\operatorname{smr}(z)\left[\mathrm{m} \mathrm{yr}^{-1}\right]$, its maximum value $s m r_{M}\left[\mathrm{~m} \mathrm{yr}^{-1}\right]$, and the vertically averaged submarine melt rate defined as $\overline{s m r}=\frac{1}{H_{T}} \int_{-H_{T}}^{0} \operatorname{smr}(z) \mathrm{d} z\left[\mathrm{~m} \mathrm{yr}^{-1}\right]$. Note that this definition averages the submarine melting over the entire water column depth. Hence, if the melting occurs preferentially in one layer (AW layer, see below), then this definition of $\overline{s m r}$ will underestimate the average melting for that layer.

\section{Line Plume Theory}

[32] Near the glacier front, the circulation addressed in this study is that of a buoyant plume rising along the vertical ice front. Its dynamics are controlled by the buoyancy forcing due to the glacier (both submarine melting along the ice front and subglacial discharge at depth), by the entrainment and mixing with the ambient fluid, and by viscous drag at the ice-ocean interface. Since the submarine melt rate depends both on the plume's velocity and its properties (see next sections), a correct representation of the buoyant plume is critical to estimating the submarine melt rate. In the simulations presented throughout the paper, even at grid spacings of 5-10 m, the turbulent buoyant plume is not fully resolved. Nevertheless, the extent to which the model captures the bulk properties of the plume can be evaluated by comparing our model runs to the theory of buoyant plumes [Morton et al., 1956; Turner, 1973]. This theory, although idealized, is a good starting point to describe the processes at play at the ice-ocean interface. If we assume that the buoyancy source due to subglacial discharge is homogeneously distributed along the glacier width, then the generated plume can be studied in analogy with the theory of line buoyant plumes in a homogeneous, nonrotating ambient fluid [Turner, 1973]. The flow variables can be expressed in terms of the buoyancy flux per unit length, $B=g^{\prime} Q s g / L$, and the distance above the source $z$. In a line buoyant plume, the buoyancy flux is constant with depth, the volume flux $Q \sim$ $B^{1 / 3} z$ increases with height above the source due to entrainment of ambient fluid, the reduced gravity $g^{\prime} \sim B^{2 / 3} z^{-1}$ decreases with height, the vertical velocity is constant, $w \sim$ $B^{1 / 3}$, and the half width of the plume $b \sim z$ increases with height above the source.

[33] Entrainment generated by the turbulent buoyant plume induces the density within the plume to increase due to mixing with denser ambient waters. Following the definition of entrainment velocity $w_{e}=\alpha w$ [Ellison and Turner, 1959], we define an entrainment flux

$$
F_{e}=\iint w_{e} \Delta \rho \mathrm{d} x \mathrm{~d} z=\alpha \iint w \Delta \rho \mathrm{d} x \mathrm{~d} z,
$$

where $\alpha$ is the entrainment coefficient, $w$ is the plume vertical velocity at a given position $(x, z)$, and $\Delta \rho$ is the difference between ambient and plume density at a given position $(x, z)$.
[34] In the simulations, the turbulent entrainment processes are not resolved but are instead parameterized by a diffusive flux

$$
F_{d}=\kappa \iint \frac{\partial \rho}{\partial x} \mathrm{~d} x \mathrm{~d} z
$$

where $\kappa$ is the horizontal diffusion coefficient, and $\rho$ is the density at a given position $(x, z)$. Therefore, a consistent representation of the buoyant plume requires the entrainment and diffusion fluxes to be of the same order of magnitude $\left(F_{e} / F_{d} \sim 1\right)$. From equations (5) and (6), this occurs when

$$
\frac{\iint w \Delta \rho \mathrm{d} x \mathrm{~d} z}{\iint \mathrm{d} \rho \mathrm{d} z} \simeq \frac{\kappa}{\alpha}
$$

where $\alpha=0.08$ is the entrainment coefficient for line plumes [Turner, 1973]. In most of the simulations discussed here, we use $\kappa=2.5 \times 10^{-1} \mathrm{~m}^{2} \mathrm{~s}^{-1}$ as the model horizontal diffusivity, which yields to values of the left-hand side of equation (7) in the range $2-7$, in good agreement with the expected value of $\frac{\kappa}{\alpha}=3.1$. Hence, we expect the model to capture the leading order dynamics of the evolving plume.

[35] To further investigate the sensitivity of the results to the exact values of the diffusivity, we perform a series of experiments in which we vary the horizontal diffusivity $\kappa$. The simulated buoyant plume density $\rho_{p}$ at $z=-450 \mathrm{~m}$ is compared with the theoretical value for line plumes, $\rho_{t}$, at the same distance above the bottom (not shown). We find that a value of $\kappa$ an order of magnitude smaller produces a lighter buoyant plume than predicted by the line plume theory (i.e., $\rho_{t}>\rho_{p}$ ) indicative of an underestimate of the entrainment flux. A slightly larger value of $\kappa=9 \times 10^{-1} \mathrm{~m}^{2} \mathrm{~s}^{-1}$ produces slightly larger plume density than in the runs with $\kappa=2.5 \times 10^{-1} \mathrm{~m}^{2} \mathrm{~s}^{-1}$. This is consistent with having a larger entrainment, further diluting the buoyant plume and increasing its density. Both results are consistent with the scaling described above. The analysis highlights that to correctly represent the dynamics of the buoyant plume generated by submarine melting and subglacial discharge, entrainment processes should be resolved or at least parameterized correctly choosing the appropriate value of $\kappa$ based on equation (7). Given that $\operatorname{Pr}=1$ in all the experiments, the above analysis is also valid for the viscosity coefficient $v$.

\section{Control Winter Experiment (WIN)}

[36] In the control run (WIN), submarine melting at the glacier front by ocean waters gives rise to a buoyant, relatively fresh plume (a mixture of glacial waters and entrained ambient waters) which rises along the vertical front. Velocities close to the glacier front are mainly vertical, while horizontal velocities become dominant with increasing distance from the glacier (Figure 3). Two distinct plumes are evident in this run, one generated by melting in the upper $150 \mathrm{~m}$, within the PW layer, which reaches the free surface, and a second plume, with density $\rho_{p}$, such that $\rho_{1}<\rho_{p}<\rho_{2}$ where $\rho_{1}\left(\rho_{2}\right)$ is the density of the upper PW (lower AW) layer, which intrudes at the interface between the two water masses. As a result, there are two distinct outflows of glacial 


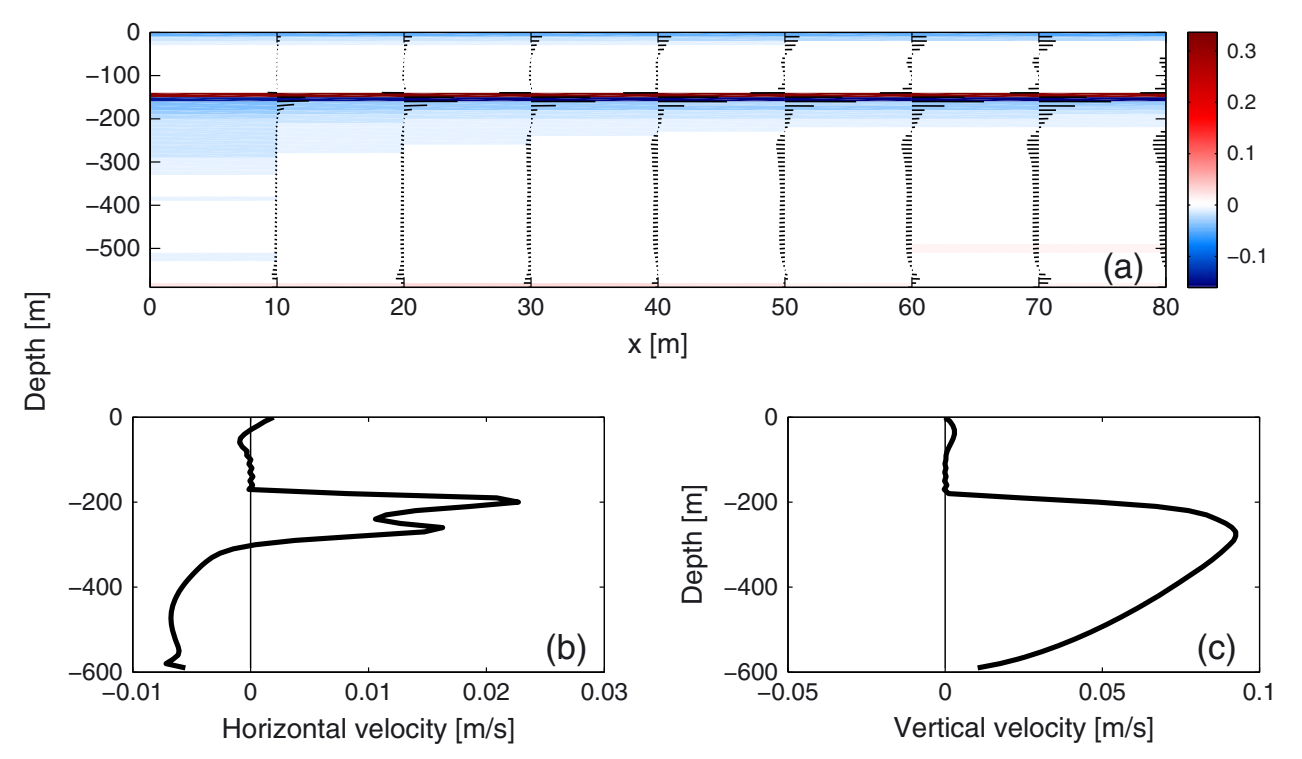

Figure 3. Control winter experiment (WIN). (a) Fjord velocities $\left(u, w\right.$, arrows, $\left.\left[m s^{-1}\right]\right)$ overlaid on the salinity anomaly ([psu], in color) with respect to the initial conditions (the glacier front is on the left side of the panel). (b) Horizontal velocity profiles averaged over $0 \leq x \leq 100 \mathrm{~m}$. (c) Vertical velocity profile at the glacier front. Thin black lines correspond to zero velocity. All quantities have been averaged over a $300 \mathrm{~h}$ period.

meltwater mixtures, one at the free surface and one at the layers' interface. Conservation of volume and entrainment processes, in turn, drive ambient waters to the glacier front in the bottom layer $(\sim 300-600 \mathrm{~m})$ and in the upper layer $\sim 80 \mathrm{~m}$ (Figure $3 \mathrm{~b}$ ) generating a "double cell" circulation consistent with that inferred from water properties collected in a winter survey of Sermilik Fjord [Straneo et al., 2011]. In our simulations, the transport in the lower cell is much larger than in the upper cell, consistent with the larger melting driven by AW compared to PW.

[37] Similarly, the plume's vertical velocity is maximum in the AW layer with a mean value in this layer of $\sim 0.04 \mathrm{~m} \mathrm{~s}^{-1}$ (Figure 3c). Within this layer, the vertical velocity increases with distance above the bottom due to the increased buoyancy flux resulting from the addition of meltwater as the plume rises. Consequently, the vertical velocity of the plume reaches its maximum at the AW/PW interface (Figure 3c). Because the submarine melt rate depends on the plume velocity, the smr also increases towards the surface in the AW layer, reaching its maximum value at the AW/PW interface. The outflow averaged horizontal velocity in the lower layer is $\sim 0.02 \mathrm{~m} \mathrm{~s}^{-1}$ (Figure 3b), even though the front, i.e., "nose," of the buoyant current has a maximum velocity of $0.09 \mathrm{~m} \mathrm{~s}^{-1}$. In our simulations, the nose of the current reaches the end of the domain $(160 \mathrm{~km})$ in $\sim 21$ days. After this time, the model shows changes in the $\overline{s m r}$ which we attribute to the impact of the open boundary on the circulation. In terms of spin-up, we see that after about $\sim 8$ days the submarine melt rate reaches a steady state. Thus, to estimate the submarine melt rate in steady conditions, we compute the $\overline{s m r}$ by averaging from day 9 to 21 of the simulation, i.e., after the transient initial period and before the open boundary affects the $\overline{s m r}$. The $\overline{s m r}$ for WIN is $70 \mathrm{~m} \mathrm{yr}^{-1}$.

\section{Sensitivity Analysis}

\subsection{Model Resolution}

[38] The sensitivity of the fjord circulation and submarine melt rate to the model resolution is estimated by varying the horizontal resolution $(\Delta x=50 \mathrm{~m}, 20 \mathrm{~m}$, and $5 \mathrm{~m})$ and then comparing the results with the control experiment. The vertical resolution is kept constant at $\Delta z=10 \mathrm{~m}$. Following Bryan et al. [1975], the horizontal grid scale Reynolds number, $\operatorname{Re}_{H}=u \Delta x / v_{H}$ where $u$ is the horizontal velocity, is kept constant and below two by changing the horizontal viscosity accordingly. Similarly, the horizontal diffusion is varied to keep the Prandtl number $P r=v_{H} / k_{H}=1$ for all the simulations. Sensitivity to horizontal grid resolution is closely related to the choice of viscosity and diffusivity parameters which have been kept constant for the winter and summer experiments. For this reason, all results described below (WIN5-WIN50) can be extended to the summer season.

[39] We find that as the resolution decreases from $10 \mathrm{~m}$ to $50 \mathrm{~m}$, the $\overline{s m r}$ decreases by a factor of 2 (Table 2). We attribute this behavior to the fact that the submarine melt rate depends strongly on the buoyant plume's vertical velocity and that, by lowering the resolution, the upwelling plume is forced to occur over a larger horizontal distance (larger than or equal to the cell width), thus resulting in lower vertical velocities. A decrease in the $\overline{s m r}$ is also found as the horizontal resolution is increased from $10 \mathrm{~m}$ to $5 \mathrm{~m}$ (Table 2). The parameterization of boundary layer processes depends on the model's resolution. In this work, we parameterize entrainment processes with diffusive and viscous coefficients (section 3 ). When using a $5 \mathrm{~m}$ horizontal resolution, we are, at the same time, partially resolving the relevant turbulence and also parameterizing it. This produces an artificially larger entrainment than is dynamically 
consistent and, therefore, a slower plume and decreased submarine melt rate.

\subsection{Velocity Dependence of the Turbulent Transfer Coefficients}

[40] When the only buoyancy source is the submarine melting (WIN), we find that the vertical plume velocity is maximum at the layers' interface and minimum at the bottom, with a mean value in the AW layer of $0.04 \mathrm{~m} \mathrm{~s}^{-1}$ (Figure 3c) which yields $\gamma_{T}=0.44 \times 10^{-4} \mathrm{~m} \mathrm{~s}^{-1}$ and $\gamma_{S}=$ $1.2 \times 10^{-6} \mathrm{~m} \mathrm{~s}^{-1}$. To examine the importance of the vertical structure of the plume's velocity and that of the turbulent transfer coefficients, we perform one experiment (WIN $\gamma$ ) where the velocity $U_{b}$ in the turbulent transfer coefficients is fixed and equal to the mean vertical velocity in the AW layer of the WIN run, and compare the results to those obtained in the WIN run.

[41] Even though the two simulations have a comparable $\overline{s m r}$ (Table 2), the variation of the submarine melt rate in the vertical is quite different (Figure 4). In the WIN $\gamma$ experiment, the melt rate depends only on the fjord water's properties and has a constant profile in the lower layer, with a slight increase with depth due to pressure effects on the freezing temperature of seawater. This is in contrast with the results of the WIN run where the submarine melting is a function of both temperature and flow velocity at the glacier front. As the buoyant plume rises, the vertical velocity increases (Figure 3c) producing larger values of submarine melt rate near the interface between the two water masses (Figure 4).

[42] By imposing a constant $\gamma_{T, S}$, one is effectively assuming that the velocity along the ice-ocean interface does not vary. The differences between the two simulations are even more evident within the PW layer, where in the WIN run, the melting is essentially zero because the plume's velocity is quite small, while in the WIN $\gamma$ run, the mean velocity used gives rise to a significant melt rate. These results suggest that not only the amplitude but also the vertical velocity structure near the glacier front has a leading order impact on submarine melt rate estimates and its vertical structure. Knowledge of these details are therefore necessary to evaluate if and how ocean forcing can affect glacier stability.

\section{Summer Experiment}

[43] The large summer surface runoff which occurs over southern Greenland gives rise to a large subglacial discharge which is likely to be a major contributor to the buoyant upwelling plume at the glacier's front. In our summer simulation (SUM), we find that the buoyancy forcing is dominated by the subglacial discharge and that its occurrence changes the amount of submarine melting dramatically.

[44] For the particular choice of subglacial discharge used in SUM, the overall features of the circulation are largely similar to those of WIN, with a double-cell circulation that is enhanced in the AW layer and at the PW/AW interface (Figure 5a). This is consistent with observations from a summer survey of Sermilik Fjord showing that glacially modified waters (containing subglacial discharge) were present in large amounts above the PW/AW interface

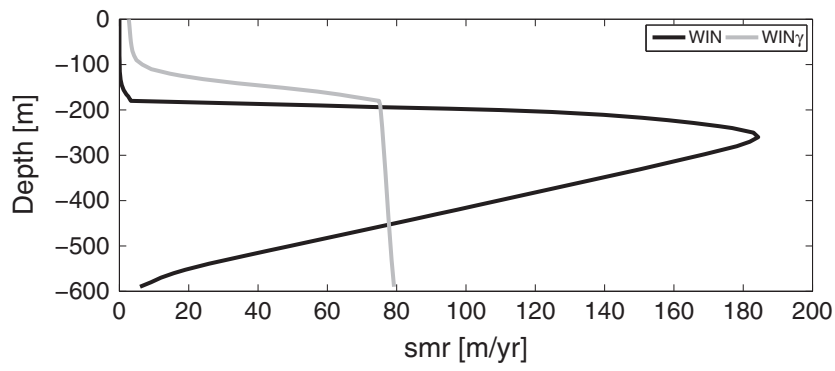

Figure 4. Vertical profiles of submarine melt rate for different parameterizations of the turbulent transfer coefficients.

and, with the inferred qualitative structure of the circulation [Straneo et al., 2011]. Yet the magnitude of the vertical velocity is much larger in SUM, and it exhibits a very different variation with depth (Figure 5c). This, in turn, gives rise to a much larger melt rate $\overline{s m r}=738 \mathrm{~m} \mathrm{yr}^{-1}$ (an order of magnitude larger) and a much larger salinity anomaly than in WIN (Figures 5a-3a, note the different scale of the colorbar).

[45] Maximum submarine melt rates in SUM are found near the bottom, and not at the layers' interface as in WIN (Figure 5b), due to the different vertical velocity profiles in the two experiments (Figure 5c). In winter, the dominant buoyancy forcing of the plume is due to the addition of water melted along the glacier front. Thus, the buoyancy forcing increases as the plume rises, and more meltwater is added. This gives rise to a vertical velocity which increases with depth and is maximum at the PW/AW interface. In summer, the large buoyancy flux due to the subglacial discharge causes the vertical velocities to have a maximum near the bottom where the water is discharged into the fjord (Figure 5c). As the buoyant plume rises, the vertical velocity decreases slightly with depth (probably due to viscous effects) which, together with the contribution from pressure effects, causes the submarine melt rate to decrease with increasing distance from the bottom.

[46] The results obtained with (SUM) and without (WIN) subglacial discharge are compared with those obtained using the Jenkins [2011] 1-D plume model with similar initial conditions and subglacial discharge. Jenkins [2011] describes the evolution of a buoyant plume by solving four ordinary differential equations for the conservation of mass, momentum, heat, and salt. The 1-D model takes into account entrainment processes by introducing a parameterization for the entrainment rate which is a linear function of the plume velocity [Ellison and Turner, 1959] $w_{e}=\alpha w$, where $w_{e}$ is the entrainment (horizontal) velocity, $\alpha$ is the entrainment coefficient, and $w$ is the plume vertical velocity (section 3 ). Figure $5 \mathrm{~b}$ shows that in both runs, the vertical profiles of submarine melt rate agree with those obtained with Jenkins' 1-D plume model (dashed lines). In winter, both profiles have a maximum at the layers' interface while in summer the maximum is at the glacier's grounding line. The vertical velocities in Jenkins' model are larger (Figure 5c), especially for the SUM run, resulting in an increased submarine melt rate compared to our simulations. The model of Jenkins [2011] is a simplified 1-D model in which the viscous forces are neglected, possibly explaining the larger 

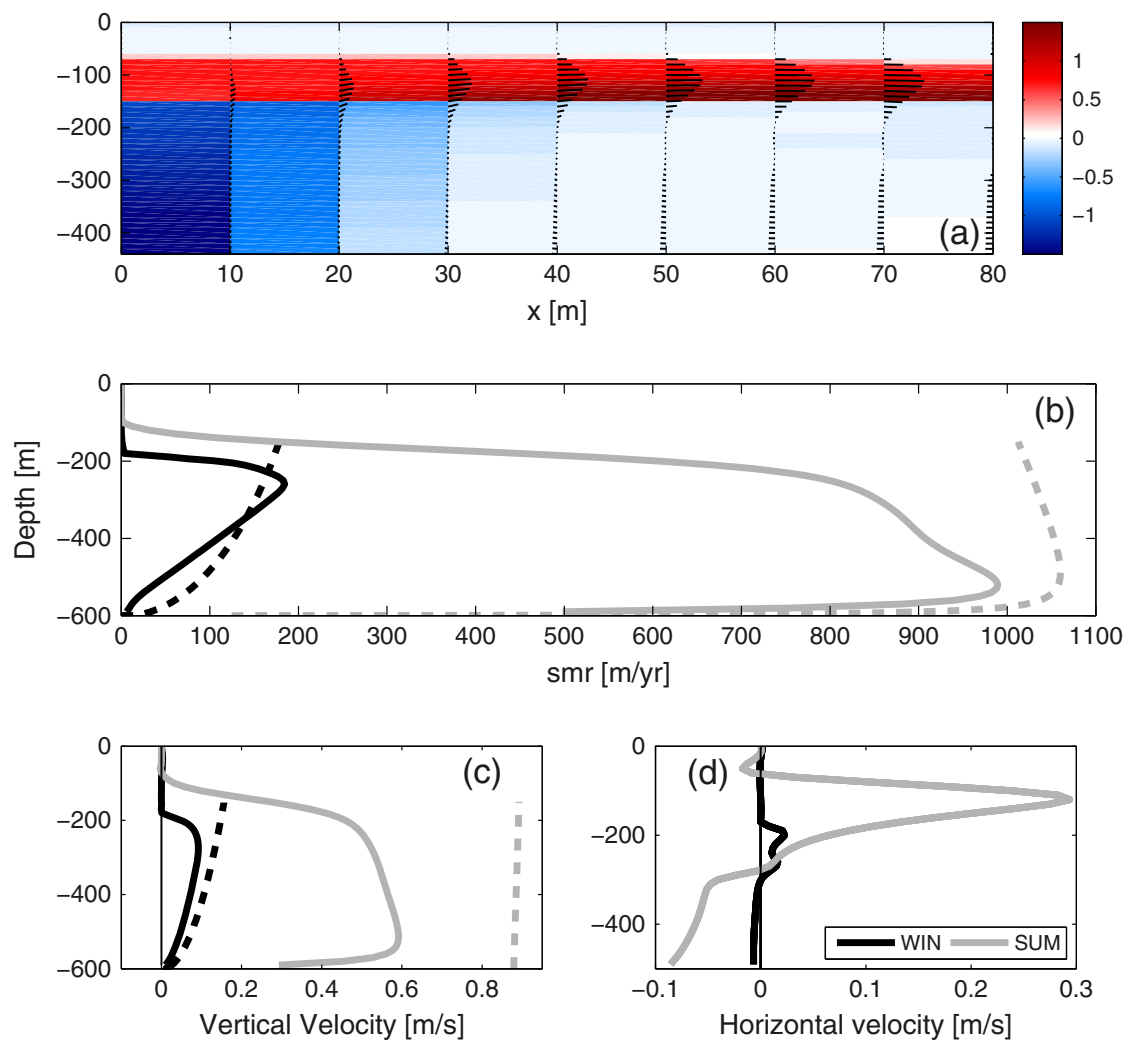

Figure 5. Comparison between summer (SUM) and winter (WIN) runs. (a) SUM fjord circulation $(u, w$, arrows, $\left[\mathrm{ms}^{-1}\right]$ ) overlaid on the salinity anomaly ([psu], in color) with respect to the initial conditions (the glacier front is on the left side of the panel). (b) Vertical profiles of submarine melt rate. (c) Vertical velocity profiles at the glacier front. (d) Horizontal velocity profiles averaged over $0 \leq x \leq 100 \mathrm{~m}$. All quantities have been averaged over a $300 \mathrm{~h}$ period. Dashed lines are profiles computed using the Jenkins [2011] plume model with the same initial subglacial discharge values in summer and $Q s g<<1$ in winter. Black (gray) lines represent winter (summer) runs. Thin black lines correspond to zero velocity.

vertical velocities compared to our 2 -D model results in which viscous forces are included. It is important to note that Jenkins' plume reaches, in both runs, its neutral buoyancy level at the interface between the two water masses, and therefore the comparison is possible only in the AW layer, which is the dynamically dominant layer as shown in Figure 5a.

[47] As discussed earlier, summer conditions in Sermilik Fjord differ from winter ones in two ways. One important difference is the summer subglacial discharge investigated above. A second difference is that the water properties observed in summer were somewhat different from those observed in winter (Figure 2). Here we examine whether adding more realistic summer water properties further affects the winter/summer differences due to the subglacial discharge described above. Therefore, in SUMs, we maintain the idealized two-layer stratification but use summer values of temperature and salinity (Table 2) while keeping all the other parameters unchanged. Our results show that the summer/winter water property differences do impact the submarine melt rate, but that overall their effect is secondary compared to the presence/absence of subglacial discharge. The model shows the same leading order dynamics in both SUM and SUMs. The lower submarine melt rate in SUMs, $\overline{s m r}=551 \mathrm{~m} \mathrm{yr}^{-1}$, compared to $\overline{s m r}=738 \mathrm{~m} \mathrm{yr}^{-1}$ found in SUM (Figure 6), is attributed to the fact that the AW temperature observed in summer was lower than that observed in winter (Table 2).

\section{Influence of Subglacial Discharge Variability}

[48] Estimates of subglacial discharge suggest large variability from hourly to seasonal to interannual timescales [Andersen et al., 2010; Mernild et al., 2010]. To investigate the sensitivity of the submarine melt rate and the plume dynamics to a varying subglacial discharge, we perform a series of experiments (SUMd). We find that both the average submarine melt rate $(\overline{s m r})$ and its maximum $\left(s m r_{M}\right)$ increase with the square root of subglacial discharge (Figure 6). For the lowest values of subglacial discharge, $Q s g=0.29 \mathrm{~m}^{3} \mathrm{~s}^{-1}, \overline{s m r}=73 \mathrm{~m} \mathrm{yr}^{-1}$ which is similar to the value obtained for the WIN simulation (Table 2). Over the explored range of Qsg, our $\overline{s m r}$ estimates are consistent with those obtained with Jenkins' 1-D plume model (Figure 6, square symbols). The difference in the power law exponent (cubic root versus square root) are not statistically significant. The small differences can be explained by the slightly 


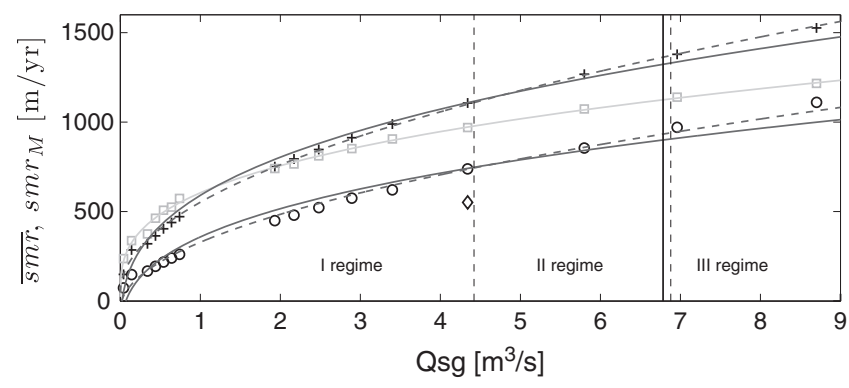

Figure 6. $\overline{s m r}$ as a function of subglacial discharge, Qsg (SUMd). Black circles represent the MITgem model and gray squares the Jenkins [2011] 1-D plume model. Black crosses represent the maximum submarine melt rate $s m r_{M}$. Black diamonds indicate the SUMs experiment. Solid curves indicate the cubic root fit of $\overline{s m r}$, and the dashed curves indicate the square root fit for the SUMd runs. The vertical dashed lines refer to the different circulation regimes found in our simulations. The solid line is the theoretical location of $\rho_{I}=\rho_{1}$ (section 7).

different vertical velocity distribution (Figure $5 \mathrm{c}$ ). In particular, the larger magnitude of Jenkins' 1-D model vertical velocities results in a larger $\overline{s m r}$ (Figure 6). Furthermore, the inclusion of a viscous term in our model gives rise to a plume whose vertical velocity decreases as it rises. This is consistent with a slightly weaker dependence (square root) on Qsg than predicted by Jenkins (cubic root). Xu et al. [2012] also found a power law of approximately one third. We are not able to make a more detailed comparison with their results because of the minimal overlap in the range of subglacial discharge (Qsg) investigated.

[49] As the subglacial discharge increases, the dynamics at the glacier front evolves into three different regimes (Figure 7). For low values of the subglacial discharge, the dynamics is characterized by the same double cell circulation described in WIN with an enhanced outflow at the interface between the two water masses as described in section 6 (regime I, Figure 7a). This regime characterizes Sermilik Fjord dynamics and is the main focus of this paper. For intermediate subglacial discharge values, the plume is more buoyant than in regime I and has larger vertical velocities. This causes it to slightly overshoot the layers' interface generating a large amplitude interfacial wave (regime II, Figure 7b). Finally, for even larger values of subglacial discharge, the plume's buoyancy is sufficient for it to penetrate through the layers' interface and reach the free surface (regime III, Figure 7c). Regime III has been previously described, in a similar setup, by $X u$ et al. [2012], who investigated the influence of large subglacial discharges, up to Qsg $=250 \mathrm{~m}^{3} \mathrm{~s}^{-1}$. For the lowest value of subglacial discharge used, $X u$ et al. [2012] may have been in the intermediate regime II as suggested by the wave in the velocity field in their Figure $2 \mathrm{a}$.

[50] The value of Qsg for which the buoyant plume is able to penetrate through the layers' interface can be estimated as follows. A buoyant plume with an initial flow rate Qsg and an initial density $\rho_{p 0}$ changes its density through entrainment of ambient waters of density $\rho_{a}$. The flow rate of entrained ambient waters is defined as

$$
Q_{e}(z)=\int_{A_{p}} w_{e} \mathrm{~d} A=\alpha w A_{p}(z)
$$

where $\alpha$ is the entrainment coefficient, $w=1.8\left(g_{0}^{\prime} Q s g\right)^{1 / 3}$ is the vertical velocity evaluated from the line plume theory [Turner, 1973], $A_{p}$ is the area through which entrainment occurs and defined as the distance from the bottom multiplied by the width of the fjord $(L=10 \mathrm{~m})$, and $g_{0}^{\prime}=$ $g\left(\rho_{p 0}-\rho_{a}\right) / \rho_{a}$ is the initial reduced gravity. The density of the plume $\rho_{p}$ is then given by

$$
\rho_{p}(z)=\frac{\rho_{p 0} \mathrm{Qsg}+\rho_{a} Q_{e}(z)}{\mathrm{Qsg}+Q_{e}(z)},
$$

and for a two-layer ambient stratification, the buoyant plume will penetrate through the interface between the two layers if the density of the plume at the layers' interface $\rho_{p}(z=$ $\left.H_{2}\right)=\rho_{I}$ is lower than the density of the upper PW layer $\left(\rho_{1}\right)$, i.e., $\rho_{I}<\rho_{1}$. Figure 6 shows that the theoretical transition to regime III, i.e., $\rho_{I}=\rho_{1}$, occurs for $Q s g=6.7 \mathrm{~m}^{3} \mathrm{~s}^{-1}$, which is in excellent agreement with the transition between regime II and III found in the model.

\section{Influence of AW Property Changes}

[51] Next, we consider the impact of variations in ocean properties on the submarine melt rate and the fjord circu-
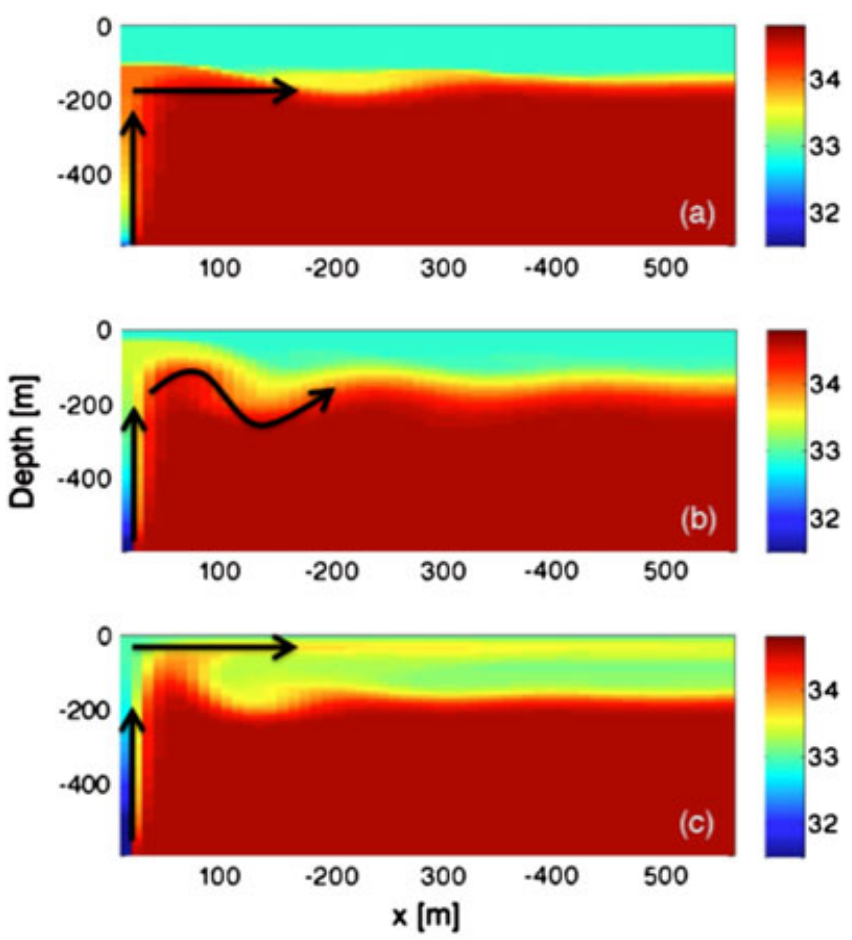

Figure 7. Salinity distribution near the glacier front (on the left side of the panels) in psu. (a) Regime I: Qsg = $0.74 \mathrm{~m}^{3} \mathrm{~s}^{-1}$, (b) regime II: Qsg $=5.8 \mathrm{~m}^{3} \mathrm{~s}^{-1}$, (c) regime III: $\mathrm{Qsg}=8.7 \mathrm{~m}^{3} \mathrm{~s}^{-1}$. Black arrows indicates the plume water pathways. 
lation. Since the PW temperature is close to freezing, its contribution to the submarine melt rate is small. Hence, we focus our attention on three likely drivers of change: (1) the temperature of the AW, $T_{2},(2)$ its thickness $H_{2}$, and (3) its salinity $S_{2}$.

[52] To investigate the impact of varying $T_{2}$, we performed a series of experiments where $T_{2}$, is varied from $0^{\circ} \mathrm{C}$ to $8^{\circ} \mathrm{C}$, while keeping the temperature of the upper layer and the salinity of both layers constant (TEMP and TEMPs runs). To investigate the influence of the relative thickness of the PW and AW layer, we varied the AW layer thickness $\mathrm{H}_{2}$ between $50 \mathrm{~m}$ and $550 \mathrm{~m}$ (INTER and INTERs runs) while keeping all other parameters constant. In the explored parameter range, we find that the structure of the circulation is not influenced by changes in $T_{2}$ and $\mathrm{H}_{2}$ but that the $\overline{s m r}$ increases linearly with $T_{2}$ and $H_{2}$ (Figure 8), both in winter (i.e., without subglacial discharge) and in summer (i.e., with subglacial discharge). A comparison with Jenkins' 1-D plume model (Figure 8, square symbols) confirms a linear dependence of $\overline{s m r}$ on $\mathrm{T}_{2}$ and $\mathrm{H}_{2}$. This linear dependence of submarine melt rate on $T_{2}$ is consistent with the scaling developed in Jenkins [2011] and the model results of $X u$ et al. [2012] who investigate only the summer season. As expected, we find that increasing $\mathrm{H}_{2}$ is comparable to increasing the $\mathrm{AW}$ temperature $T_{2}$. For example, increasing the lower layer thickness from $450 \mathrm{~m}$ to $500 \mathrm{~m}$ is comparable to increasing the temperature of the AW by $1^{\circ}$ from $4^{\circ} \mathrm{C}$ to $5^{\circ} \mathrm{C}$ (Figure 8). Holland et al. [2008] found a quadratic dependence of $\overline{s m r}$ on water temperature and showed that previous results are highly variable. Depending on the type of study (e.g., modeling versus observational), the $\overline{s m r}$ had a linear or quadratic dependence on water temperature. We find that, in the temperature range explored here, the difference between a quadratic and liner dependence is not statistically significant. We note that the dependence of the $\overline{s m r}$ on $\mathrm{H}_{2}$ deviates slightly from the linear dependence, and this subtle difference may be explained again by the vertical velocity dependence with depth found in our runs which is absent in Jenkins' 1-D plume model (Figure 5c).

[53] Next, we investigate the impact of changes in the AW salinity by varying $S_{2}$ in the range $34-35$ psu (SALT and SALTs runs). From our own observations and historical data in the Irminger Sea (not shown), AW salinity variations are unlikely to exceed this range. In summer, a 1 psu increase corresponds to a $13 \%$ decrease in $\overline{s m r}$ from $776 \mathrm{~m} \mathrm{yr}^{-1}$ to $686 \mathrm{~m} \mathrm{yr}^{-1}$. In winter, $\overline{s m r}$ is less sensitive to AW salinity changes with a $4 \%$ decrease from $69 \mathrm{~m} \mathrm{yr}^{-1}$ to $66 \mathrm{~m} \mathrm{yr}^{-1}$ for a 1 psu increase (Figure 8).

[54] A 1 psu change in salinity impacts both the density of the AW layer and the freezing point temperature. The corresponding density change of $\sim 0.79 \mathrm{~kg} \mathrm{~m}^{-3}$ at the base of the glacier is still much less than the PW/AW density difference, and similarly, the freezing point temperature changes of only $0.05^{\circ} \mathrm{C}$. These variations are negligible compared to the dynamical effect of salinity on the plume. The plume buoyancy flux increases with increasing salinity resulting in a increase in the plume vertical velocity (section 3). However, the plume will entrain denser water resulting in a higher plume density. Even though we observe a faster plume (not shown) which locally melts more, the $\overline{s m r}$ is less because the plume melts over a shorter vertical distance from the bottom. The model results indicate that
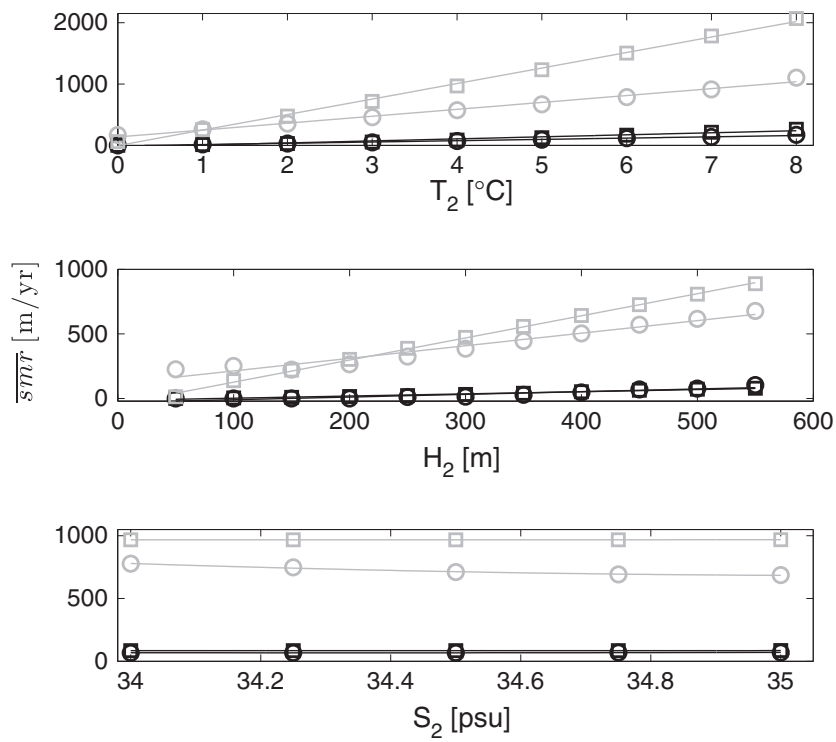

Figure 8. Vertically averaged submarine melt rate $(\overline{s m r})$ as a function of $T_{2}, H_{2}$, and $S_{2}$. Gray (black) symbols denote experiment with (without) subglacial discharge. Circles represent the MITgcm model and squares the Jenkins [2011] 1-D plume model. Solid lines are linear fits.

the plume dynamical regime transitions from regime II to regime I as the salinity increases from 34 to 35 psu and, as visible in Figures $7 \mathrm{a}$ and $7 \mathrm{~b}$, as the buoyant plume becomes heavier, it will intrude less into the PW layer resulting in a lower submarine melting.

\section{Summary and Conclusions}

[55] We use a fjord scale, nonhydrostatic general circulation model to investigate the circulation and submarine melt rate resulting from the presence of a glacier at the head of a long, deep fjord. The setup is meant to be an idealized representation of the Sermilik Fjord/Helheim Glacier system in southeast Greenland. We examine variations forced by changes in the properties of the two water masses observed in the fjord (the cold, fresh Polar Water layer and the warm, salty Atlantic Water layer) and in the rate of subglacial discharge.

[56] Our simulations indicate that the fjord's two-layer stratification gives rise to a double cell circulation where relatively fresh water (containing glacial melt) is exported both at the free surface and at the interface between the two water masses. Hence, large amounts of glacially modified waters are exported below the PW layer. Even though the general structure of the circulation is the same in summer and winter, our results indicate that both the vertical distribution and magnitude of the submarine melt rate vary strongly between seasons. During summer, the rate of submarine melt is an order of magnitude larger than during winter. It is maximum at the glacier's base, compared to a maximum at the interface between the two water masses found during winter. These differences are primarily due to the large subglacial discharge that occurs in summer. This discharge results in a large and fast buoyant plume, which in turn, enhances the submarine melt rate along the glacier front by affecting the 
ice-ocean transfer processes. Physically, the summer plume is much more buoyant, resulting in a more turbulent plume with larger entrainment rates and larger transport of heat towards the glacier. In winter, the only buoyancy forcing is due to melting of the glacier itself, giving rise to a less buoyant and slower plume. As a result, the vertically averaged submarine melt rate is an order of magnitude smaller than in summer. Substantial changes in the submarine melt rate can also result from changes in the Atlantic Water layer thickness and temperature, while the Atlantic Water salinity has a smaller impact on the dynamics and the submarine melt rate. Our results show that vertically averaged submarine melt rate varies with the square root of the subglacial discharge, and linearly with the Atlantic water temperature and layer thickness.

[57] Our results are in fairly good agreement with the cubic-root scaling developed by Jenkins [2011] and Jenkins' 1-D plume model, indicating that simplified onedimensional plume models are useful tools to understand the first-order dynamics regulating the melting at the glacier front. The use of a general circulation model presents some advantages when compared to the simpler plume model in that we could identify different regimes of the circulation driven by the glacier itself. A scaling argument indicates that to generate the "double cell" circulation characterizing Sermilik Fjord dynamics (regime I), the buoyant plume density at the layers' interface $\rho_{I}$ must be less than the density of the upper PW layer which, for the parameters of Sermilik Fjord, occurs for $Q s g<6.7 \mathrm{~m}^{3} \mathrm{~s}^{-1}$, in excellent agreement with our simulation (Figure 6). Our results are also consistent with some of the findings of $X u$ et al. [2012]. In their study, however, they focused on a regime in which the meltwater plume penetrates all the way to the ocean free surface and generates a single outflowing current which is approximately $100 \mathrm{~m}$ deep and with very large horizontal velocities (of the order of $2 \mathrm{~m} \mathrm{~s}^{-1}$ ). Such circulation and large velocities are not observed in Sermilik Fjord, and the Xu et al. [2012] results are not readily applicable to Sermilik and similar environments.

[58] Our estimates indicate that the summer melt rates are of the order of $700 \mathrm{~m} \mathrm{yr}^{-1}$ while winter melt rates are about $70 \mathrm{~m} \mathrm{yr}^{-1}$ and that this difference is largely due to subglacial discharge. Caution must be used, however, in converting these estimates to average values over the entire submerged front of a glacier such as Helheim since they were obtained for a $10 \mathrm{~m}$ wide glacier. In winter, when there is no subglacial discharge, we expect the $10 \mathrm{~m}$ wide glacier to be representative of the entire portion of the glacier in contact with the ocean. Therefore, the $70 \mathrm{~m} \mathrm{yr}^{-1}$ melt rate estimate is likely to be representative of a mean melt rate for Helheim as long as the transfer coefficients used in the ice/ocean boundary layer parameterization are appropriate. In summer, however, the estimate of $700 \mathrm{~m} \mathrm{yr}^{-1}$ melt rate is only appropriate for the fraction of the glacier characterized by a large subglacial discharge, and not necessarily for the entire glacier front. Thus, even though it is tempting to compare the summer melt rate with the recent estimate of $400-1000 \mathrm{~m} \mathrm{yr}^{-1}$ obtained using synoptic velocity and temperature profiles collected in Sermilik Fjord during summer 2009 [Sutherland and Straneo, 2012], the comparison is not appropriate. Given that the model-based estimate is only representative of a portion of the glacier, one could speculate that average melt rates across the entire glacier front should be considerably less and thus at odds with the field-based estimate. For example, one should consider a $700 \mathrm{~m} \mathrm{yr}^{-1}$ over $400 \mathrm{~m}$ and $70 \mathrm{~m} \mathrm{yr}^{-1}$ over the remaining glacier's width which results in a $\overline{s m r}=112 \mathrm{~m} \mathrm{yr}^{-1}$. On the other hand, the field-based estimate of Sutherland and Straneo [2012], is indicative of the quasi-instantaneous (field data were obtained in less than a week) melt rate averaged across the entire glacier front. In practice, there are multiple reasons why we should be cautious about making this comparison. First, the data-based estimate itself is highly uncertain and based on a snapshot of conditions inside the fjord. Furthermore, it is important to remember that the model simulations are highly idealized in nature and only consider the circulation driven by the glacier itself. A potentially important dynamical feature neglected in the model simulation is, for example, the fast and rapidly changing continental shelf-forced circulation observed in Sermilik Fjord [Straneo et al., 2010; Sutherland and Straneo, 2012]. A second, likely source of discrepancies is due to the fact that the turbulent transfer coefficients are largely untested in Greenlands tidewater glacier environment.

[59] Several important simplifications have been made in this study. First, we have assumed that the leading order dynamics is two-dimensional. This assumption is justified for the fjord scale circulation but is questionable for localized subglacial discharges which may introduce spatial asymmetries in the problem, something which needs to be investigated further. Second, large uncertainties remain regarding the timing and magnitude of the subglacial discharge. Here, we have made an attempt to cover what we consider is a realistic dynamical range. Yet until the uncertainties in these numbers are reduced, it is hard to identify an appropriate dynamical regime. Third, we have assumed that even though the model does not explicitly resolve the smaller turbulent scales of the problem, their integral effect is captured by the parameterizations of eddy viscosity and diffusivity. We have presented a scaling argument which supports this assumption in the dynamical range explored here, but further studies with even higher resolution models are needed. Fourth, key to these experiments is an appropriate parameterization of the ice-ocean boundary. This study shows that the submarine melt rate and its vertical structure can vary substantially depending on the choice of parameters and variables in the turbulent transfer coefficients. Given our present knowledge of the turbulent transfer coefficients, our results indicate that a correct estimate of the vertical velocities is crucial to represent the ice-ocean dynamics and the submarine melt rate, in particular. More work is needed to determine whether the parameterization of this dynamics is appropriate for models that cannot resolve the small-scale nonhydrostatic boundary layer processes at the ice-ocean interface. Our results suggests that models such as the one used here could help bridge the gap between small-scale and large-scale models that are unlikely to resolve the dynamics at the ice-ocean boundary. For example, the derived relationship between submarine melt rates and subglacial discharge (Figure 6) could be integrated in melt rate parameterizations of large-scale models. A formulation not depending on near-ice front vertical velocities might also lend itself for inclusion in isopycnal models with a fundamentally different vertical discretization 
(e.g., Adcroft and Hallberg [2006]) and implied plume and entrainment parameterization.

[60] Albeit very simplified, this study illustrates the suitability of using a GCM to investigate the dynamics driving glacier melting and is a necessary step to investigate the importance of fjord circulations on the dynamics near a glacier front. We find that the inclusion of a variable velocity in the turbulent transfer coefficients is fundamental to capture the seasonal variability of the vertical structure of $\overline{s m r}$. Larger subglacial discharge induces larger vertical velocities, resulting in larger submarine melt rates. Hence, the quantification of the subglacial discharge and the number and size of drainage channels is fundamental for a correct prediction of submarine melting and fjord circulation. By varying the AW layer thickness from $450 \mathrm{~m}$ to $500 \mathrm{~m}$, we find that the submarine melt rate is increased by the same amount as if the temperature of the AW was increased by $1^{\circ}$ from $4^{\circ} \mathrm{C}$ to $5^{\circ}$. Hence, the displacement of the interface between AW and PW may be as, if not more, important than a temperature change in the AW layer.

[61] Finally, these idealized experiments have neglected a whole range of oceanic/fjord processes which likely have a strong impact on the heat transport to the glacier and hence the submarine melt rate. These include circulations forced by continental shelf and atmospheric variability at the mouth, local winds, and tides. The interaction between these circulations and the buoyancy-driven circulation described here is the subject of ongoing research. Such process studies are crucial to improve our understanding of the dynamic response of Greenland's outlet glaciers to oceanic and atmospheric forcings [Straneo et al., 2013].

[62] Acknowledgments. We thank Adrian Jenkins for making his 1-D plume model available to us. Support to CC and FS was given by the National Science Foundation project OCE-1130008. CC received support also from the WHOI Arctic Research Initiative. RS and PH are supported in part by NSF project OCE-1129746. Additional funding for RS comes through ISAC-CNR U.O.S. Torino as part of the projects SHARE PAPRIKA and EU FP7 ACQWA, and for PH through NASA/MAP project NNX11AQ12G (ECCO-ICES).

\section{References}

Adcroft, A., and R. Hallberg (2006), On methods for solving the oceanic equations of motion in generalized vertical coordinates, Ocean Modell., $11,224-233$.

Adcroft, A., C. Hill, J. Marshall, and P. Heimbach (2004), Overview of the formulation and numerics of the MIT GCM, in Proceedings of the ECMWF: Seminar Series on Numerical Methods, Recent Developments in Numerical Methods for Atmosphere and Ocean Modelling, edited by ECMWF, 139-149.

Andersen, M. L., et al. (2010), Spatial and temporal melt variability at Helheim Glacier, East Greenland, and its effect on ice dynamics, J. Geophys. Res., 115, F04041, doi:10.1029/2010JF001760.

Andreasen, J. (1985), Seasonal surface-velocity variations on a sub-polar glacier in West Greenland, J. Glaciol., 31, 319-323.

Azetsu-Scott, K., and F. C. Tan (1997), Oxygen isotope studies from Iceland to an East Greenland Fjord: Behaviour of glacial meltwater plume, Mar Chem., 56(3-4), 239-251.

Bamber, J., M. van den Broeke, J. Ettema, J. Lenaerts, and E. Rignot (2012), Recent large increases in freshwater fluxes from Greenland into the North Atlantic, Geophys. Res. Lett., 39 (19), L19,501, doi:10.1029/2012GL052552.

Bryan, K., S. Manabe, and R. C. Pacanowski (1975), A global oceanatmosphere climate model - Part II , The oceanic circulation, J. Phys. Oceanogr., 5(1), 30-46.

Catania, G. A., T. A. Neumann, and S. F. Price (2008), Characterizing englacial drainage in the ablation zone of the Greenland ice sheet, J. Glaciol., 54(187), 567-578.

Cazenave, A., and W. Llovel (2009), Contemporary sea level rise, Ann. Rev. Mar. Sci., 2(1), 145-173, doi:10.1146/annurev-marine-120308-081105.
Chow, V. (1959), Open-Channel Hydraulics, McGraw-Hill, New York.

Christoffersen, P., R. I. Mugford, K. J. Heywood, I. Joughin, J. A. Dowdeswell, J. P. M. Syvitski, A. Luckman, and T. J. Benham (2011), Warming of waters in an East Greenland fjord prior to glacier retreat: Mechanisms and connection to large-scale atmospheric conditions, The Cryosphere, 5(3), 701-714.

Chu, V., L. Smith, A. Rennermalm, R. Forster, J. Box, and N. Reehy (2009), Sediment plume response to surface melting and supraglacial lake drainages on the Greenland ice sheet, J. Glaciol., 55(194), 1072-1082.

Das, S. B., I. Joughin, M. D. Behn, I. M. Howat, M. A. King, D. Lizarralde, and M. P. Bhatia (2008), Fracture propagation to the base of the Greenland ice sheet during supraglacial lake drainage, Science, 320(5877), 984-986.

Ellison, T. H., and J. S. Turner (1959), Turbulent entrainment in stratified flows, J. Fluid Mech., 6(03), 423-448.

Hanna, E., J. Cappelen, X. Fettweis, P. Huybrechts, A. Luckman, and M. H. Ribergaard (2009), Hydrologic response of the Greenland ice sheet: The role of oceanographic warming, Hydrol. Processes, 23(1), 7-30.

Heimbach, P., and M. Losch (2012), Adjoint sensitivities of sub-ice-shelf melt rates to ocean circulation under the pine island ice shelf, West Antarctica, Ann. Glaciol., 53(60), 59-69.

Hellmer, H. H., and D. J. Olbers (1989), A two-dimensional model for the thermohaline circulation under an ice shelf, Antarct. Sci., 1(04), 325-336.

Holland, D. M., and A. Jenkins (1999), Modeling thermodynamic iceocean interactions at the base of an ice shelf, J. Phys. Oceanogr., 29(8), 1787-1800.

Holland, P. R., A. Jenkins, and D. M. Holland (2008), The response of ice shelf basal melting to variations in ocean temperature, Journal of Climate, 21(11), 2558-2572.

Howat, I. M., I. Joughin, and T. A. Scambos (2007), Rapid changes in ice discharge from Greenland outlet glaciers, Science, 315(5818), 1559-1561.

Howat, I. M., I. Joughin, M. Fahnestock, B. E. Smith, and T. A. Scambos (2008), Synchronous retreat and acceleration of southeast Greenland outlet glaciers 2000-2006: Ice dynamics and coupling to climate, $J$. Glaciol., 54(646-660)

Huang, R. (1993), Real freshwater flux as a natural boundary condition for the salinity balance and thermohaline circulation forced by evaporation and precipitation, J. Phys. Oceanogr., 23, 2428-2446.

Huppert, H., and E. Josberger (1980), The melting of ice in cold stratified water, J. Phys. Oceanogr., 10, 953-960.

Huppert, H. E., and J. S. Turner (1980), Ice blocks melting into a salinity gradient, J. Fluid Mech., 100(2), 367-384.

Jackett, D. R., and T. J. McDougall (1995), Minimal adjustment of hydrographic profiles to achieve static stability, J. Atmos. Oceanic Technol., 12(2), 381-389.

Jenkins, A. (1991), A one-dimensional model of ice shelf-ocean interaction, J. Geophys. Res., 96(C11), 20,671-20,677, doi:10.1029/91JC01842.

Jenkins, A. (2011), Convection-driven melting near the grounding lines of ice shelves and tidewater glaciers, J. Phys. Oceanogr., 41, C08043, doi:10.1029/2007JC004368.

Jenkins, A., H. H. Hellmer, and D. M. Holland (2001), The role of meltwater advection in the formulation of conservative boundary conditions at an ice-ocean interface, J. Phys. Oceanogr., 31(1), 285-296.

Jenkins, A., K. W. Nicholls, and H. F. J. Corr (2010), Observation and parameterization of ablation at the base of ronne ice shelf, Antarctica, $J$. Phys. Oceanogr., 40(10), 2298-2312.

Joughin, I., W. Abdalati, and M. Fahnestock (2004), Large fluctuations in speed on Greenland's Jakobshavn Isbrae glacier, Nature, 432(7017), 608-610.

Legg, S., and A. Adcroft (2003), Internal wave breaking at concave and convex continental slopes, J. Phys. Oceanogr., 33, 2224-2246.

Legg, S., R. Hallberg, and J. Girton (2006), Comparison of entrainment in overflows simulated by z-coordinate, isopycnal and non-hydrostatic models, Ocean Modell., 11(1-2), 69-97.

Losch, M. (2008), Modeling ice shelf cavities in a $\mathrm{z}$ coordinate ocean general circulation model, J. Geophys. Res., 113, C08043, doi:10.1029/2007JC004368.

MacAyeal, D., and S. Jacobs (1985), Evolution of tidally triggered meltwater plumes below ice shelves, Antarct. Res. Ser., 43, 133-143.

Magaldi, M. G., T. W. N. Haine, and R. S. Pickart (2011), On the nature and variability of the East Greenland spill jet: A case study in summer 2003, J. Phys. Oceanogr., 41, 2307-2327.

Marshall, J., A. Adcroft, C. Hill, L. Perelman, and C. Heisey (1997a), A finite-volume, incompressible Navier Stokes model for studies of the ocean on parallel computers, J. Geophys. Res., 102 (C3), 5753-5766, doi:10.1029/96JC02775.

Marshall, J., C. Hill, L. Perelman, and A. Adcroft (1997b), Hydrostatic, quasi-hydrostatic, and nonhydrostatic ocean modeling, J. Geophys. Res., 102(C3), 5733-5752, doi:10.1029/96JC02776. 


\section{SCIASCIA ET AL.: FJORD DYNAMICS AND SUBMARINE MELTING}

Marshall, J., H. Jones, and C. Hill (1998), Efficient ocean modeling using non-hydrostatic algorithms, J. Mar. Syst., 18(1-3), 115-134.

Mernild, S. H., G. E. Liston, I. M. Howat, Y. Ahn, K. Steffen, B. Hasholt, B. H. Jakobsen, B. Fog, and D. van As (2010), Freshwater flux to Sermilik Fjord, SE Greenland, The Cryosphere Discussions, 4, $1195-1224$.

Milne, G. A., W. R. Gehrels, C. W. Hughes, and M. E. Tamisiea (2009), Identifying the causes of sea-level change, Nat. Geosci., 2, 471-478.

Morton, B. R., G. Taylor, and J. S. Turner (1956), Turbulent gravitational convection from maintained and instantaneous sources, P. Roy. Soc. Lond. A Mat., 234(1196), 1-23.

Motyka, R. J., L. Hunter, K. A. Echelmeyer, and C. Connor (2003), Submarine melting at the terminus of a temperate tidewater glacier, LeConte Glacier, Alaska, USA, Ann. Glaciol., 36(1), 57-65.

Motyka, R. J., M. Truffer, M. Fahnestock, J. Mortensen, S. Rysgaard, and I. Howat (2011), Submarine melting of the 1985 Jakobshavn Isbræ floating tongue and the triggering of the current retreat, J. Geophys. Res., 116, F01007, doi:10.1029/2009JF001632.

Mueller, R. D., L. Padman, M. S. Dinniman, S. Y. Erofeeva, H. A. Fricker, and M. A. King (2012), Impact of tide-topography interactions on basal melting of Larsen C Ice Shelf, Antarctica, J. Geophys. Res., 117(C05005), doi:10.1029/2011JC007263.

Mugford, R. I., and J. A. Dowdeswell (2011), Modeling glacial meltwater plume dynamics and sedimentation in high-latitude fjords, $J$. Geophys. Res., 116, F01023, doi:10.1029/2010JF001735.

Murray, T., et al. (2010), Ocean regulation hypothesis for glacier dynamics in southeast Greenland and implications for ice sheet mass changes, $J$. Geophys. Res., 115, F03026, doi:10.1029/2009JF001522.

Rignot, E., and P. Kanagaratnam (2006), Changes in the velocity structure of the Greenland ice sheet, Science, 311(5763), 986-990.

Rignot, E., M. Koppes, and I. Velicogna (2010), Rapid submarine melting of the calving faces of West Greenland glaciers, Nature Geosci., 3(3), 187-191.

Schjøth, F., C. S. Andresen, F. Straneo, T. Murray, K. Scharrer, and A. Korablev (2012), Campaign to map the bathymetry of a major Greenland fjord, Eos Trans. $A G U, 93(14), 141$.

Schodlok, M. P., D. Menemenlis, E. Rignot, and M. Studinger (2012), Sensitivity of the ice-shelf/ocean system to the sub-ice-shelf cavity shape measured by NASA IceBridge in Pine Island Glacier, West Antarctica, Ann. Glaciol., 53(60), 156-162.

Spall, M. A. (2011), On the role of eddies and surface forcing in the heat transport and overturning circulation in marginal seas, Journal of Climate, 24(18), 4844-4858.

Stearns, L. A., and G. S. Hamilton (2007), Rapid volume loss from two East Greenland outlet glaciers quantified using repeat stereo satellite imagery, Geophys. Res. Lett., 34, L05503, doi:10.1029/2006GL028982.

Steele, M., G. L. Mellor, and M. G. Mcphee (1989), Role of the molecular sublayer in the melting or freezing of sea ice, J. Phys. Oceanogr., 19(1), 139-147.
Straneo, F., G. Hamilton, D. Sutherland, L. Stearns, F. Davidson, M. Hammill, G. Stenson, and A. Rosing-Asvid (2010), Rapid circulation of warm subtropical waters in a major glacial fjord in East Greenland, Nat. Geosci., 3(3), 182-186.

Straneo, F., R. Curry, D. Sutherland, G. Hamilton, C. Cenedese, K. Vage, and L. Stearns (2011), Impact of fjord dynamics and glacial runoff on the circulation near Helheim Glacier, Nat. Geosci., 4(5), 322-327.

Straneo, F., D. Sutherland, D. Holland, C. Gladish, G. Hamilton, H. Johnson, E. Rignot, Y. Xu, and M. Koppes (2012), Characteristics of ocean waters reaching Greenland's glaciers, Ann. Glaciol., $53(60)$, 202-210.

Straneo, F. et al. (2013), Challenges to understand the dynamic response of Greenlands marine terminating glaciers to oceanic and atmospheric forcing, Bull. Am. Meteorol. Soc., in press, doi:10.1175/BAMS-D-1200100 .

Sutherland, D. A., and F. Straneo (2012), Estimating ocean heat transports and submarine melt rates in Sermilik Fjord, Greenland, using lowered acoustic Doppler current profiler (LADCP) velocity profiles, Ann. Glaciol., 53(60), 50-58.

Thomas, R. H. (2004), Force-perturbation analysis of recent thinning and acceleration of Jakobshavn Isbrae, Greenland, J. Glaciol., 50(168), 57-66.

Truffer, M., and K. A. Echelmeyer (2003), Of isbrae and ice streams, Ann. Glaciol., 36(1), 66-72.

Turner, J. (1973), Buoyancy Effects in Fluids, Cambridge University Press, Cambridge, UK.

van den Broeke, M., J. Bamber, J. Ettema, E. Rignot, E. Schrama, W. J. van de Berg, E. van Meijgaard, I. Velicogna, and B. Wouters (2009), Partitioning recent greenland mass loss, Science, 326(5955), 984-986.

Vieli, A., and F. Nick (2011), Understanding and modelling rapid dynamic changes of tidewater outlet glaciers: Issues and implications, Surv. Geophys., 32(4-5), 437-458.

Visbeck, M., J. Marshall, and H. Jones (1996), Dynamics of isolated convective regions in the ocean, J. Phys. Oceanogr., 26(9), 1721-1734.

Wells, A. J., and M. G. Worster (2008), A geophysical-scale model of vertical natural convection boundary layers, J. Fluid Mech., 609, $111-137$.

Xu, Y., E. Rignot, D. Menemenlis, and M. Koppes (2012), Numerical experiments on subaqueous melting of Greenland tidewater glaciers in response to ocean warming and enhanced subglacial runoff, Ann. Glaciol., 53(60), 229-234.

Yaglom, A. M., and B. A. Kader (1974), Heat and mass transfer between a rough wall and turbulent fluid flow at high Reynolds and Péclet numbers, J. Fluid Mech., 62, 601-623, doi:10.1017/S0022112074000838.

Zwally, H. J., W. Abdalati, T. Herring, K. Larson, J. Saba, and K. Steffen (2002), Surface melt-induced acceleration of Greenland ice-sheet flow, Science, 297(5579), 218-222. 